NBER WORKING PAPER SERIES

\title{
BRETTON WOODS AND THE GREAT INFLATION
}

\author{
Michael D. Bordo \\ Barry Eichengreen \\ Working Paper 14532 \\ http://www.nber.org/papers/w14532
}

\section{NATIONAL BUREAU OF ECONOMIC RESEARCH 1050 Massachusetts Avenue Cambridge, MA 02138}

December 2008

Paper presented at the NBER Conference on the Great Inflation Woodstock, Vermont, September 2008. The views expressed herein are those of the author(s) and do not necessarily reflect the views of the National Bureau of Economic Research.

NBER working papers are circulated for discussion and comment purposes. They have not been peerreviewed or been subject to the review by the NBER Board of Directors that accompanies official NBER publications.

(C) 2008 by Michael D. Bordo and Barry Eichengreen. All rights reserved. Short sections of text, not to exceed two paragraphs, may be quoted without explicit permission provided that full credit, including (C) notice, is given to the source. 
Bretton Woods and the Great Inflation

Michael D. Bordo and Barry Eichengreen

NBER Working Paper No. 14532

December 2008

JEL No. N1,N2

\begin{abstract}
$\underline{\text { ABSTRACT }}$
In this paper we show that the acceleration of inflation in the United States after 1965 reflected a shift in perceived responsibility for managing the country's international financial position. Prior to 1965 this responsibility was lodged primarily with the Fed, whose policies resembled those of a central bank playing by the gold standard rules of the game. Over time, however, this responsibility was increasingly assumed by the Treasury, while the Federal Reserve acquired increasing room for maneuver as a result of the adoption of the Interest Equalization Tax and other policies with effects analogous to capital controls. Once the external constraint shaped policy less powerfully, the Fed pursued other goals more aggressively, resulting in more inflationary pressure. We document these points with a quantitative and qualitative analysis of the minutes of the Federal Open Market Committee.
\end{abstract}

Michael D. Bordo

Department of Economics

Rutgers University

New Jersey Hall

75 Hamilton Street

New Brunswick, NJ 08901

and NBER

bordo@econ.rutgers.edu

Barry Eichengreen

Department of Economics

University of California, Berkeley

549 Evans Hall 3880

Berkeley, CA 94720-3880

and NBER

eichengr@econ.Berkeley.edu 


\section{Bretton Woods and the Great Inflation Michael Bordo and Barry Eichengreen ${ }^{1}$ November 2008}

\section{Introduction}

There is no shortage of explanations for the Great Inflation - for the acceleration of inflation in the late 1960s in the United States. A first interpretation is that policy makers mistakenly adopted a nonmonetary view of inflation as driven by idiosyncratic (“cost push”) factors and disregarded monetary policy as a tool for containing price-level increases. ${ }^{2}$ A second cites price-level disturbances in combination with a monetary policy rule that caused policy makers to accommodate the resulting inflationary pressures. ${ }^{3}$ And a third interpretation is that policy makers mistakenly concluded that they could attain a permanently higher level of output by accepting a higher rate of inflation. ${ }^{4}$

There is insight to be gained from each of these views. We neither dispute their validity nor run a horserace between them. ${ }^{5}$ But we argue that a full understanding of how and why policy makers allowed inflation to accelerate in the second half of the 1960s

\footnotetext{
${ }^{1}$ Rutgers University and NBER, and University of California, Berkeley and NBER, respectively. This paper was prepared for the NBER Conference on the Great Inflation, Woodstock, Vermont, September 25-27, 2008. We are grateful to Owen Humpage and Michael Shenk at the Cleveland Fed for facilitating our reading and analysis of the FOMC minutes. We also thank Hyun Hak Kim for able research assistance.

${ }^{2}$ See Nelson (2005). In effect they saw inflation as unresponsive to aggregate demand and therefore to monetary policy actions.

${ }^{3}$ See Clarida, Gali and Gertler (2000).

${ }^{4}$ As emphasized by Sargent (1999) and Romer and Romer (2002).. Some compounded this error by overestimating the output gap. This is the argument of Orphanides $(2003,2004)$, to which we return below. Others assumed the existence of an exploitable output-inflation relationship but perceived a steepening of the tradeoff, encouraging them to accept higher inflation in order to maintain unemployment at low levels. See Taylor (1997) and Primiceri (2005).

${ }^{5}$ Indeed it can be argued that the three categories of explanation described in this paragraph are not entirely distinct from one another. But that is a topic for another paper.
} 
requires one also to understand why the same factors did not operate previously - what it was, in other words, that restrained inflationary tendencies in earlier years.

Here our emphasis differs from that in the previous literature. We argue that Federal Reserve policy prior to the Great Inflation - for present purposes the period 19591965 - resembled that of a central bank following the gold standard rules of the game. ${ }^{6}$ The stability of the dollar exchange rate (under Bretton Woods, the dollar price of gold) was a priority for policy. Hence balance-of-payments developments that could undermine the stability of the exchange rate drew a sharp reaction. A potentially inflationary increase in aggregate demand that threatened to suck in imports and crowd out exports elicited an increase in rates. Accelerating inflation that augered a deterioration in international competitiveness similarly caused the Fed to tighten. The value attached by the Fed to the stability of the exchange rate was public knowledge. Thus, when demand increased and the balance of payments weakened, awareness that the Fed would tighten limited the inflationary consequences. The Fed's commitment to following the Bretton Woods rules of the game anchored expectations. It limited inflationary inertia and prevented inflation from taking off in response to shocks. ${ }^{7}$

The attentive reader will note that we have shifted from referring to the gold standard rules to the Bretton Woods rules. This usage is intended to flag that we are

\footnotetext{
${ }^{6}$ Prior to 1959 the same policy priorities prevailed, but this being the period of the dollar shortage the balance-of-payments constraint was rarely binding. For more on this see Section 3 below.

${ }^{7}$ In arguing that lifting the exchange rate anchor altered expectations and in turn forced policy makers to respond in ways that validated inflationary expectations, we are applying the expectations-trap model popularized by Clarida, Gali and Gertler (2000) and Christiano and Gust (2000). However, neither of these treatments mentions the exchange rate or links the exchange rate regime to the expectations trap. Armenter and Bodenstein (2005) suggest that an expectations trap is less likely under a pegged than a flexible exchange rate, but they do not refer to Bretton Woods.
} 
referring not to the simple textbook characterization of the rules of the game under the gold standard, according to which a central bank mechanically responds to reserve increases and losses and disregards other possible influences on policy, but to a more nuanced version in which the central bank is also influenced by other factors. We are not arguing that balanceof-payments considerations were the only factor shaping policy. ${ }^{8}$ We are not even arguing that they were always, or even usually, the most important factors in the decisions of the FOMC, although as we show below they in fact dominated on a number of occasions. But we are arguing that close attention to the role of balance-of-payments concerns is necessary in order to understand why Fed policy was even less inflationary in the first half of the 1960s than one would expect on the basis of the Taylor rule. ${ }^{9}$

What changed after 1965 was not just the model of the economy and the priorities of policy makers, these being the emphases of much of the previous literature, but also perceptions of the assignment of tasks. In the earlier period, defending the dollar had been perceived as a shared responsibility of the Treasury and the Fed, with the latter assuming a significant share of the burden. But starting when it negotiated a gold pooling arrangement with foreign central banks and pushed through the Interest Rate Equalization Tax, Treasury and more broadly the Administrative Branch assumed more responsibility for defense of the dollar. The Fed perceived itself as freer to pursue other goals.

This perceptual shift was further encouraged by policies that can be thought of as quasi capital controls, like the just-mentioned Interest Equalization Tax. These policies

\footnotetext{
${ }^{8}$ In practice, precisely the same can be said of the $19^{\text {th }}$ century and interwar gold standard years. See Eichengreen, Watson and Grossman (1985).

${ }^{9}$ A fact that we document in Section 5 below.
} 
loosened the link between inflation and the exchange rate. They relaxed the constraints that had shaped monetary policy and anchored expectations in prior years. They allowed the Fed to rationalize more expansionary policies. Now if the central bank adopted more expansionary policies, it did not have to worry to the same extent as before that this would cause the balance of payments to deteriorate. And if the balance of payments did in fact deteriorate, it was now the Treasury rather than the Fed that was primarily responsible for dealing with the consequences. ${ }^{10}$

On occasions when balance of payments pressure rose to alarming levels, which still could happen given the permeability of the quasi-controls, the Fed responded as before. But it did so less regularly. Together with the knowledge that the central bank now felt freer to pursue other goals, this meant that the exchange rate commitment anchored expectations less effectively. Moreover, the view, whether valid or not, that a different government agency, Treasury, was now primarily responsible for the stability of the dollar and the balance of payments, a responsibility that it also had the capacity to discharge, encouraged the belief within the Fed that inflation could be allowed to accelerate without violating one its key objectives, which was to maintain the stability of the dollar. It fostered the belief that the central bank could pursue high employment more aggressively while remaining less vigilant about inflation than before.

What is different in our account from the previous literature? We do not depart from other recent work describing a growing inclination not just in the Fed but also in the Executive Branch to enlist monetary policy in the pursuit of full employment and growth

\footnotetext{
${ }^{10}$ Which it could do by increasing taxes on foreign investments, reducing military spending abroad, and adopting other fiscal expedients.
} 
even if they were attained at the cost of price stability. We do not dispute accounts emphasizing how the Fed increasingly disregarded the inflationary consequences of its policies in order to pursue other goals. But we offer a different explanation for why the monetary policy makers felt free to do so. This explanation also points to a different periodization than most of the earlier literature. We see the Great Inflation as taking off in 1965, since this was when the reassignment of predominant responsibility for exchange rate stability became clear. Scholars emphasizing other factors point in contrast to the late 1960s or the early 1970s. While it may have taken until then for the full extent of inflationary pressures to be unleashed, the precipitating shift in the policy framework, we argue, occurred around 1965 and critically involved the perception that primary responsibility for the dollar exchange rate had shifted to the Treasury. ${ }^{11}$

Section 2 presents an overview of Fed policy and its motivations in the 1960s based on the Board of Governor's Annual Reports. Section 3 then uses narrative evidence from the minutes of the Federal Open Market Committee to develop our view that balance-ofpayments considerations played a key role in shaping monetary policy decisions before 1965 and exercised a restraining influence on inflation. Section 4 shows that this situation changed subsequently. Section 5 then supplements this analysis of narrative record with a variety of bits of statistical evidence pointing in the same direction, after which Section 6 concludes. $^{12}$

\footnotetext{
${ }^{11}$ Statistical evidence (below) suggests that the inflation process ratcheted up in several steps in the course of the 1960s and early 1970s; our interpretation points to changes in the perception and priority attached to balance-of-payments concerns as explaining the first ratchet around 1965.

${ }^{12}$ Appendix 1 describes the measures adopted by the Treasury to contain balance of payments pressure in the 1960s.
} 


\section{An Overview of FOMC Decision Making}

If the dollar and the balance of payments were of concern to the Fed and influenced the conduct of policy prior to 1965, then this should be evident in the words and deeds of the Federal Open Market Committee. We take two approaches to determining whether this was the case. In this section we construct a summary of FOMC policy actions from the Board of Governors' Annual Report. Following that, in the next two sections we flesh out those policy actions with a narrative of the period and quotes from FOMC minutes.

For every FOMC meeting from 1959 to 1971 we describe the policy decision taken, the reason given for it (whether domestic or international or both), the number of dissents, the direction of the dissents, and whether the concept of "even keel” was invoked. ("Even keel" was the name given to the post-Accord policy of the Fed, which sought to facilitate Treasury funding operations by stabilizing the Treasury bill market while also pursuing other objectives; see Markese 1973.)

The upper panel of Figure 1 shows policy actions: decisions to tighten are the positive bars, while decisions to ease are the negative bars. For decisions to keep policy unchanged, no bar is shown. In addition we indicate whether the actions were taken primarily for domestic reasons (white bars) or primarily for international reasons (black bars) or for a combination of both reasons (cross hatched bars). ${ }^{13}$ We also show in the upper panel of Figure 1 the key policy instruments that the FOMC referred to at the time: the federal funds rate, the 90 day Treasury bill rate, and the discount rate.

\footnotetext{
${ }^{13}$ Appendix 2 presents the data underlying Figure 1. In addition to the information in the figure, it shows the number of attendees present and absent at each meeting and the vote taken. Information from the Federal Reserve Board's Annual Reports was gathered and summarized with the help of Michael Shenk of the Federal Reserve Bank of Cleveland.
} 
The lower panel shows the dissents. The bars above the line indicate that the dissenter wanted a tighter policy than enacted, while the bars below the line indicate that the dissenter wanted policy to be looser than what was enacted. The length of the bars indicates the number of dissents. Their colors indicate the division between domestic, international and mixed, as in the upper panel.

The number of meetings with black bars indicating policy actions motivated primarily by international considerations is not large (7 out of a total of 210) all of which indicated increased restraint. These cases are concentrated before late 1965, although they also appear occasionally thereafter at times that are associated with a dramatic deterioration in the balance of payments, such as the aftermath of sterling's devaluation in late 1967 and the collapse of the Gold Pool in 1968.

The number of meetings where there are cross-hatched bars indicating that a combination of domestic and international factors motivated the policy is considerable: there are 23 of these. These meetings which also indicated increased restraint occurred both before 1965 and during crisis periods in 1967, 1968 and 1971.

We do not read this evidence as indicating that balance of payments considerations dictated monetary policy decisions in the first half of the 1960s, any more than they strictly dictated central bank decision making under the prewar and interwar gold standards. Rather, we see concern over the balance of payments as tipping the balance - but often importantly so, at least in the period before 1965. 


\section{Narrative Evidence, 1959-65}

Having shown what the FOMC did and provided a summary characterization of why, we now recount what it said about its decisions in more detail. In this section we focus on the period when balance-of-payments considerations repeatedly influenced the Committee's policy decisions. Section 4 paints the contrast with the subsequent period. ${ }^{14}$

Economic policy under the Eisenhower administration emphasized balanced budgets, price stability and maintenance of the Bretton Woods peg to gold at \$35 an ounce. Federal Reserve Chairman William McChesney Martin also was a firm believer in adherence to the gold peg. He was supported by a number of FOMC members, especially Alfred Hayes, President of the Federal Reserve Bank of New York, who throughout the Bretton Woods period advocated policy tightening to protect the monetary gold stock and offset incipient balance of payments deficits.

Until the beginning of 1959, when Western European countries attained current account convertibility, there was little pressure on U.S. gold reserves. 1959 was the first time when significant concern was voiced about the stability of the dollar. The 1959-60 recession, largely engineered by tight monetary policy, led to both price deflation and a gold inflow in the classical manner. ${ }^{15}$ FOMC minutes document that the Fed's decision to maintain a tight policy was importantly influenced by balance-of-payments considerations.

\footnotetext{
${ }^{14}$ We also searched for other bits of narrative evidence, for example in the memoirs of Treasury and Federal Reserve officials. One who speaks to the issues at hand is Charles Coombs, who was responsible for international operations at the New York Fed. He alludes indirectly to the kind of shift of perceived responsibility from the Fed to the Treasury that we emphasize here, although he places it somewhat later, at the time when the Nixon Administration took office and Fowler and Deming took over at Treasury ("The role of the Federal Reserve in foreign financial policy was severely curtailed after the accession of the Nixon administration in January 1969.") See Coombs (1976), p.xii, 190-191.

${ }^{15}$ For more detail see Meltzer (2009 forthcoming), Chapter 2.
} 
For example, at the FOMC on January $6^{\text {th }}$, 1959, when the vote was to maintain policy, President Hayes said that "it was possible that when questions had been raised about the stability of the dollar, an action taken on the disciplinary side of System monetary policy would bring credit rather than discredit on System intentions. If nothing else it was quite likely that our upward movement of Treasury Bill yields in the United Sates to equality with or above, the yield on Treasury bills in the United Kingdom would tend to stem the outflow of gold from the United States. Moreover it might draw gold back to this country because of more attractive investment opportunities offered in the U.S. Government securities market” (p.19). ${ }^{16}$

Then on October $4^{\text {th }}, 1960$ when the action taken was to maintain the current stance of decreased restraint, Mr. Treiber of the Federal Reserve Bank of New York emphasized how it was "important that the United States act promptly and wisely to rectify the balance of payments deficit. Failure to do so will more and more circumscribe the ability of the Federal Reserve to pursue a flexible monetary policy...” (p.16). President Leach of the Federal Reserve Bank of Boston warned that “ More ease...would not be of material assistance to the economy, but would affect the balance of payments adversely and could make the task of monetary policy more difficult in the future” (p.30). Also at the October $25^{\text {th }}, 1960$ meeting, when the policy directive was to maintain decreased restraint, the accompanying statement for the first time recognized the balance of payments problem. The Federal Reserve Bank of New York was “directed to [conduct open market operations] in light of current and prospective economic conditions ... with a view ...(b) to

\footnotetext{
${ }^{16}$ Page numbers indicated in parentheses in this section refer to the page in the minutes of the FOMC meeting cited on which the quoted material appears.
} 
encouraging monetary expansion for the purpose of fostering sustainable growth in economic activity and employment, while taking into consideration current international developments...”

Hayes elaborated the point. "We have recognized right along, ever since our balance of payments became seriously adverse in 1958, that although domestic considerations must be our main concern, we could not ignore the international implications of our actions. It so happened that during this time our policies were well suited to both domestic and international conditions... but this has no longer been true during much of 1960, and last month’s gold episode [when the London price of gold spiked to $\$ 40.00$ per ounce on the fears that a Kennedy administration would be inflationary] should serve as dramatic evidence that we are dealing with a complex and sensitive problem with respect to the international financial position. Undoubtedly one of the causes of the gold speculation has been fear that this country might want to unduly loosen monetary and fiscal policies in an effort to combat recessionary tendencies" (p.16). "It seems to me that the balance of payments deficit, with all of the complications which may accompany it in the way of gold sales and loss of confidence in the dollar confronts all Americans with an extremely serious if not almost intractable problem... All of this argues strongly for our avoiding further overt measures of monetary ease, such as a discount rate cut, unless they are clearly called for by the state of the domestic economy....and I do not think they are at present” (p.170). Canby Balderston of the Board of Governors agreed, stating that he "would favor a change in the directive such as Mr. Hayes had suggested [while inserting "while taking into consideration current international developments"]. The 
gold outflow was part of the total problem; to ignore it would be unwise and might reflect on the System in the future” (p.43).

On November $22^{\text {nd }}$, 1960 when the decision was to keep policy unchanged, Chairman Martin stated that "he continued to believe that the balance of payments problem was the most important problem for the country to deal with at this time. This was because he believed it to be the most significant shadow in the domestic business picture, and the only way he could point this up was to say that the credit of the U.S. was now in danger” (p.41). Then on January $10^{\text {th }}, 1961$, when the policy action continued to be to maintain the policy of the previous year, A.L. Mills of the Board of Governors stated that "[i]n his view, it would be much more in order to permit the reserve position of the bank to tighten to a degree that would find the short-term interest rate moving up from its artificially low level which would be conducive to checking the outflow of funds and possibly recovering it...the economic affairs of the country had reached a point where it became necessary to use monetary policy as a surgical scalpel to correct dramatically a very difficult international financial situation....it was a serious responsibility of the Federal Reserve Banks and of the members of Board of Governors to take into account first the international situation and to consider what detailed steps should be taken that would be most conducive to a more harmonious international financial position” (p.29).

There is a good deal of narrative evidence, then, that balance-of-payments considerations figured in the considerations of members of the FOMC, leading to a policy of a more restrained monetary policy than might have prevailed otherwise. 
Elected in the fall of 1960 with a mandate to "get America moving again" and a commitment to restore full employment, President John F. Kennedy also believed firmly in the importance of maintaining the gold parity. Pressure on gold reserves and a growing balance of payments deficit, reflecting U. S. private and public foreign investment in excess of the current account surplus, emerged as important problems in these years. U. S. Treasury under Secretary Douglas Dillon and Under Secretary Robert Roosa supplemented the efforts of the Fed to stem the dollar outflow, intervening in the foreign exchange market, developing a network of swap agreements with other countries starting in March 1961 (an arrangement in which the Fed joined a year later), issuing Roosa bonds (foreign-currencydenominated U.S. Treasury securities), creating the IMF’s General Agreements to Borrow, and establishing the London Gold Pool. ${ }^{17}$ While the Fed continued to pay considerable attention to the balance of payments when determining the stance of policy, the increased activism of the Treasury in complementing its efforts helped to set the stage for the subsequent period when the Fed felt free to delegate responsibility for the dollar and the balance of payments to Treasury.

FOMC meetings between 1961 and 1964 featured vigorous debate between those, usually including Chairman Martin, who advocated tight policy to defend the dollar and the proponents of looser conditions designed to stimulate growth and reduce unemployment. On multiple occasions, stalemate between the two groups led to no change in policy. In our view, policy almost certainly would have been loosened in a number of these instances

\footnotetext{
${ }^{17}$ The swap arrangements were an attempt to create credit lines big enough to finance short-term balance of payments pressures on the scale that might be suffered by the United States. The Gold Pool, for its part, was an arrangement designed to limit conversion of dollars into gold by foreign central banks.
} 
absent the importance attached by the first faction to balance-of-payments considerations. In addition, on several occasions the FOMC voted to raise rates in part to protect the balance of payments: specific instances of the latter included December $18^{\text {th }}, 1962$, May $7^{\text {th }}$, 1963 and July $30^{\text {th }}$, 1963. The second and third of these increases were part of Operation Twist, conducted in cooperation with the Treasury, under which the Fed raised short-term interest rates to stem capital outflows while the Treasury lowered long-term rates to stimulate domestic investment. Again, we would argue that these increases would have been unlikely had balance-of-payments considerations not tipped the balance.

At its meeting on August $1^{\text {st }}, 1961$, the FOMC had voted to maintain its policy stance. The statement explaining this decision contained an explicit reference to the balance of payments deficit. “...to encourage expansion of bank credit and the money supply so as to contribute to strengthening the focus of recovery, while giving consideration to international factors...” (p.57). Moreover, several Committee members argued vigorously for tightening policy in response to the deteriorating international position. According to Treiber, "[o]bservers abroad are likely to interpret excessive ease here, particularly as symbolized by a low T-bill rate, as indication of an unwillingness or inability on the part of the U.S. to take the steps necessary to assure the soundness of the dollar” (p. 23). Mr. Deming, a non-voting FOMC participant, suggested further that "[a]s to the directive, in the light of recent developments in Europe he would suggest the possibility of inserting the word "increased" before "considerations " in the phrase of clause (b) [of the directive] now reading "while giving consideration to international factors” (p. 31). And Rouse, manager of the System Open Market Account, warned that 
"[t]he questions that had been asked of him [by the BIS governors] about Government expenditures, the Federal budget, and related matters were indication of a background of concern about possible developments in this country over a period of time. They indicated a feeling that the U.S. ultimately would have to resolve the same questions that the British were trying to resolve at the present time” (p.55).

In the meeting on October $3^{\text {rd }}$, 1961 , the Committee again voted to keep policy unchanged, and its statement again spoke of the need for attention to the balance of payments. Some members advocated going further and made the case for tightening in response to deteriorating balance-of-payments conditions. Thus, Charles Shepardson of the Board of Governors expressed his view that "it would be fortunate if there was some rise in the bill rate in the light of the international situation" (p. 12). As Mills put it, "the disparity between short-term interest rates in this country and Great Britain argues for higher rates in this country as a hindrance against renewed gold losses and...to counter inflationary influences” (p. 13). Again, these last words are an important reminder that concern over the balance of payments was not always the only or the most important factor, but this narrative evidence should make clear that it figured importantly in the minds of some members.

At its October $24^{\text {th }}$, 1961 meeting, the FOMC again voted to maintain the current policy while again appending a caution concerning the balance of payments. A growing number of Committee members invoked deteriorating balance-of-payments conditions as reason for tightening. As President Irons of the Federal Reserve Bank of Dallas put it, "In terms of the domestic situation...it would seem reasonable to continue about the same 
degree of ease that had existed during the past three weeks. However the international situation presented a problem calling for a somewhat different conclusion. The forthcoming Treasury refunding... suggests maintaining the status quo. Balancing these out, the Committee might do well to give more attention to firming short-term rates in order to provide relief on the international side without creating instability or undue restriction in the domestic market” (p.21). Mr. Clay of the Federal Reserve Bank of Kansas City expressly referred to the impact of Fed policy on capital flows when he observed that "the Manager of the System Open Account would need to conduct open market operations with a view to keep the treasury bill rate from going too low relative to rates abroad (page 29). Mr. Heflin of the Federal Reserve Bank of Richmond cautioned that "the delicate and uneasy position of the dollar suggested that it would be unwise to move toward additional ease...” (p.31). Mills warned that "a start [must be] made toward implementing a moderately restraining monetary and credit policy... The skeptical attitude to Federal Reserve system policies that has been taken by domestic and foreign monetary experts, and which is a factor in the weakness of the dollar on the international exchanges and in renewed gold losses, is perhaps the strongest reason that urges a revision of policy thinking...” (p.33). Balderston asked rhetorically "whether the transfer abroad of gold and dollars plus the widened interest differential between New York and London, was serious enough to give concern. To this question his answer was in the affirmative” (p.49). Finally, Hayes acting as Chairman in Martin's absence warned "that on balance the System would lose more by standing aside than by doing what it could to indicate that it saw danger on the international exchanges...he then said he thought that at least a goodly number of those 
around the table had expressed some concern about the international problem and had recognized that there was perhaps something the System could do to help, in a minor way, to show that it was aware of the problem, without doing damage to the domestic economy” (p.51).

Again at the meeting on November 14, the vote was for no change, but now there were dissents in favor of tightening for balance-of-payments reasons. In the opinion of Treiber, "[t]he most disturbing factor now before us is our poor balance of payments... The rise in short-term rates since last month...should be helpful from the international viewpoint...As for the directive, it seems to me that in light of international factors and the basic strength of the domestic economy, the committee could properly change the directive so as to put less emphasis on encouraging credit expansion and greater emphasis on international factors” (p.24). Here, clearly, balance-of-payments concerns had tipped the opinion of at least one FOMC member in favor of tightening, although they had not yet convinced the majority.

Then on December $19^{\text {th }}$, 1961, the FOMC voted 8 to 4 in favor of increased restraint for both domestic and international reasons. Hayes was not satisfied; he pushed for even greater attention to the balance of payments. He wished to change the directive to read "giving special attention to international factors" instead of "giving consideration to international factors' (p.13). His change was not adopted. Then at the next meeting on January 23, the FOMC voted to maintain the degree of tightening from the previous meeting, again mentioning the balance of payments. Once more Hayes pushed for tightening to help the international situation by raising the discount rate. As he put it, "This 
country is just too easy a place in which to borrow and not a sufficiently attractive place in which to invest. As the domestic economy continues to improve, we can very well afford to take steps to modify this set of conditions and try to induce some return flow of capital...In terms of open market policy this means that we should edge towards less ease...In our Bank...[we] have done a good deal of soul-searching lately on the subject of a possible discount rate increase. The balance of payments problem is serious enough to raise the question whether we could not act on the rate in advance of a market rate rise, in order to emphasize the increase as a signal of our determination to do our part in meeting the critical international problem” (p.11).

A series of meetings then passed without additional reference to the balance of payments. But at the December $18^{\text {th }}, 1962$ meeting, the FOMC voted to increase restraint primarily for international reasons, although there were five dissents. Hayes strongly supported the decision. "In his judgment the balance of payments situation was the biggest single shadow over the domestic business picture. He did not believe that a slightly less easy monetary policy [to alleviate the balance of payments deficit] would in any sense collapse the domestic economy. In fact such a change in emphasis might lead to a strengthening of confidence” (p.61).

There followed a series of meetings where the policy of December 1962 was maintained and both Hayes and Martin pushed for more attention to external balance. As Hayes put the case on February $12^{\text {th }}$, "the magnitude of the balance of payments problem is much too great to be solved by monetary policy alone. Nevertheless, monetary policy can and should play an important part, and I would hope that it could do so simultaneously with 
a ... well publicized program on the part of the Administration to achieve equilibrium in our international payments, including a substantial net reduction in military and aid disbursements abroad and a firm policy towards greater discipline in the area of production costs” (p.20). Chairman Martin reinforced the point, observing that "if the System had been derelict in 1962 it was probably in paying a minimum of attention to the balance of payments problem. There was little question in his mind but that a crisis was approaching...” (p.48). At the next meeting, on March $5^{\text {th }}$, the vote was again to maintain, and both Hayes and Martin again stressed the balance of payments. Hayes put it this way: 'The outflow of gold was resumed last week and the prospect is for substantial gold sales during the coming month...we are clearly getting closer to the danger point as the gold stock diminishes while the balance of payments deficit continues unabashed...Admittedly a move toward lesser ease would involve some risk with respect to the domestic economy...they are minor risks compared with the growing danger to the dollar's international standing....There might ...be an opportunity later in the month for an increase in the discount rate if the System was willing to give a clear signal of its concern for our international position” (p.47). And “[w]ith respect to the balance of payments... [Chairman Martin] continued to feel that conditions were gradually moving toward a crisis of some sort...too much attention has been paid to stimulating the domestic economy through monetary policy and not enough for dealing with the balance of payments...the balance of payments problem had become the real shadow over the domestic business scene” (p.82). On June $18^{\text {th }}$, 1963 , for a third time the vote was to maintain, although Hayes and others now pushed for an increase in the discount rate to ease the international situation. As 
Hayes put it, "the time for decision is at hand ...the continued gravity of the international position leaves us little choice, especially in the light of the Treasury’s calendar...An increase of one half percent in the discount rate in the near future could be expected to serve two very important purposes; 1 . to signal to the foreign monetary authorities and to the world in general that the System is ready to use traditional tools of monetary policy to defend the international position of the dollar, and 2. to achieve a level of short-term market rates that should cause a substantial repatriation of short funds” (p.22). Braddock Hickman, an alternate member of the FOMC, was more to the point. "The raising of interest rates," he stated, "might deter some investments but at the same time it would represent a forward step in dealing with the balance of payments problem...” (p.54).

By the time of the July $9^{\text {th }}, 1963$ meeting, sentiment for tightening, primarily for balance of payments reasons, had become more widespread. According to Hayes "the dollar has clearly reached a vulnerable stage. The forthcoming gold losses caused by French purchases will tend to unsettle the exchange markets and there are increasingly ominous signs of apprehension and impatience among central banks in Europe...[it] behooves us to demonstrate that progress is being made on the balance of payments front before the apprehension reaches crisis proportions. For years there has been a heavy shortterm drain... and it seems wholly reasonable to believe that an appreciable firming of shortterm rates in this country would check the flow and might then bring a reversal. In addition it could have very important psychological effects by signaling...the determination of the System to have a strong dollar...the System would be prepared to take positive actions as soon as possible in the form of a one half per cent increase in the discount rate... [the New 
York Fed] directors have felt for some time that we should be giving greater emphasis to our international responsibilities...it would be important for the System to act in advance of rather than after, any administration announcement of a systemic attack on the balance of payments problem” (pp.29-31). Hickman again echoed the point: “In so far as policy over the next 3 months was concerned... a shift was not only appropriate but long overdue. The domestic economy continued to move ahead and the balance of payments to deteriorate. [I] would recommend moving immediately toward a higher term structure of interest rates...” (p.40). Chairman Martin stated his willingness to "support an increase in the discount rate...[as] part of a concerted attack on the balance of payments problem” (p.70). Again, we are not arguing that balance of payments considerations were the exclusive or even the primary explanation for the 50 basis point increase in the discount rate decided on July 17. But they clearly played an important role in tipping the balance of opinion in favor.

There was little further discussion of the balance of payments for the remainder of 1963 or in early 1964 although "contributing to improving the balance of payments” was always in the directive.. At that point the issue resurfaced. On June $17^{\text {th }}$, 1964 the FOMC voted to leave policy unchanged. But Hayes once again pushed for tightening to strengthen the balance of payments, though acknowledging that conditions were not conducive for such a move. “[Our] bargaining position in international financial matters has been dramatically weakened as our cumulative deficit has grown. We cannot afford to let the situation continue for long without taking decisive steps to check it. ...the balance of payments outlook would justify our taking a clear step toward less credit ease at this time. [I admit] the difficulty of obtaining much public support for such a move in the virtual 
absence of immediate inflation development here in this country and against the favorable first quarter balance of payments. Also the imminence of treasury financing is an important inhibiting factor. Thus I am led to the reluctant conclusion that we should stay our hand, in so far as an immediate policy move is concerned” (p.24).

Again in the autumn of 1965 Hayes and others expressed concern about inflation and the deteriorating balance of payments and pressed for a 50 basis point increase in the discount rate. At the meeting on October 12, 1965 he noted that "concern over prices and costs seems to be particularly warranted by the unsatisfactory state of the balance of payments and the prospect that we may have trouble keeping the U.S. trade surplus up to its present level in view of the likelihood that imports will be strongly stimulated by the business expansion... the effort to reach ultimate [balance of payments] equilibrium without the need of artificial barriers will...call for a strong concerted effort including an appropriate contribution by monetary policy...,...Looking ahead ...[I] have a real basis for concern about potential inflation pressure, against a background of cumulative large increases in bank credit and a serious international payments problem that leaves us little margin for assuming inflation risk...[I see] an increase in the discount rate as the most appropriate method of signaling a move toward greater firmness in monetary policy and validating the firming that has already occurred in market rates...I think a one half per cent increase [in the discount rate] is fully justified if we look only at international factors” (pp.24-26). Balderston, supported Hayes’ position. “[A]n increase in the discount rate...internationally ...should [lead to] a new measure of confidence in the dollar, and perhaps seek interest rate incentives to investment in the U.S.” (p.67). This time Chairman 
Martin was more cautious. "With a divided Committee and in the face of strong Administrative opposition he didn't believe it would be appropriate for him to lend his support to those who favored a change in policy now... he hoped the debate about the role of monetary policy in dealing with the balance of payments could be shifted away from the question whether the deficit can be entirely overcome by interest rate action alone...he did not believe that was possible” (p.69-71).

On November $23^{\text {rd }}, 1965$ Hayes reiterated the point. "In my judgment this combination of circumstances [inflationary pressure and adverse balance of payments] points to a clear policy conclusion. The time has come for an overt move to signal a firm monetary policy, and an increase in the discount rate by one half per cent is the appropriate means of affecting such a change... he is prepared to recommend that the New York directors vote a one half percent discount rate increase within the next week or so” (p.3536). Now support came from additional quarters. According to President Ellis of the Federal Reserve Bank of Boston, "it was evident that further measures would be required to restrain capital outflow. One such measure, a move towards lesser ease would not only buttress the special credit restraint measures being employed but would serve as a widely understood monetary signal that would strengthen the willingness to hold dollars abroad” (p.35). Dewey Daane of the Board of Governors added that "[l]ast but not least on [his] list of economic reasons for a System policy change was the deterioration in the U.S. balance of payments...” (p.69).

At the December $6^{\text {th }}$ meeting Hayes observed that although the rise in the discount rate and the revision of Regulation Q ceilings would “prove valuable both in extending the 
duration of the present business upswing and in bolstering the international position of the dollar... [there is] need for Open Market policy to back up official rate action...Any threat to reasonable price stability also has serious implications for our balance of payments deficit” (p.25). The FOMC agreed, and voted for a 50 basis point hike in the discount rate. This was the decision that led the president to verbally attack Martin during the chairman's visit shortly thereafter to the LBJ ranch, an experience that Meltzer and others argue significantly weakened Martin’s anti-inflationary resolve. ${ }^{18}$

\section{Narrative Evidence 1966-71}

There was then little reference to balance-of-payments considerations in 1966 or the first half of 1967. In the spring of 1966 the Fed tightened policy because of concern about inflationary pressures. This led to a credit crunch later in the year. In the face of pressure from the housing industry and Congress the Fed shifted its policy in favor of ease early in 1967 (Meltzer forthcoming, chapter 4). In this period international reserves improved very briefly although the monetary gold stock kept declining (Bordo 1993). The return to looser monetary policy was then reflected in continued deterioration in the balance of payments. In this environment, it appears that the Fed simply did not feel the same responsibility for addressing those balance-of-payments problems as before. Now day-to-day responsibility for such matters fell to Treasury. Only when a major threat to the stability of the dollar developed did the Fed feel compelled to address it.

\footnotetext{
${ }^{18}$ See Meltzer (forthcoming).
} 
The first such threat was the fallout from the sterling crisis in the autumn of 1967. In addition to raising the discount rate by 50 basis points on November $20^{\text {th }}$, 1967 , the day after sterling was devalued, the FOMC voted to raise rates further in the next meeting on November $27^{\text {th }}, 1967$ and also at the December $12^{\text {th }}$ meeting. Not just this timing but also the minutes confirm that concerns for the stability of the dollar were heavily responsible for these decisions. According to Mr. Treiber, not tightening would lead to "[i]nflation [that] would weaken the position of the dollar internationally at the very time our worldwide efforts require that confidence be sustained and strengthened” (p.40). Irons emphasized that "the deterioration in the balance of payments situation was a significant factor...[he therefore] proposed some reduction in the prevailing degree of ease” (p.48). According to Charles Coombs, Special Manager of the System Open Market Account, "In the event of [sterling's] devaluation, he would favor having the System devote all of its attention to protecting the dollar” (p.39). Andrew Brimmer of the Board of Governors “urged the need for contingency planning against a possible devaluation not only to the international finance area but also in connection with the use of domestic policy instruments” (p.39). Sherman Maisel of the Board of Governors concluded "that an increase in the Federal Reserve discount rate should be considered in connection with contingency planning against the probability of devaluation of sterling” (p.49).

At the meeting on November $27^{\text {th, }} 1967$, Maisel again voiced concern that "the U.S. might find itself in the same position as the British had recently” (p.43). A variety of expedients to defend the dollar while avoiding the need to tighten monetary policy were considered. Mr. McLaury of the Federal Reserve Bank of New York recommended that 
the Fed use forward operations as a means of reducing the inflow of dollars into foreign central banks... he [viewed] the proposed provision of forward cover [as] an alternative to a tighter domestic monetary policy as a means of limiting dollar accrual by foreign central banks “ (pp.43-45). Ellis recommended augmenting the swap line. Still, he acknowledged that "[o]ne important ingredient of a program to defend the dollar in the short-run might very well be convincing evidence that the Committee intended to contribute to that defense in the long-run through its domestic monetary policy...the Committee should make it clear that it intended to validate the discount rate action through open market operations” (p.72). There was then little discussion of the balance of payments in the minutes until the Gold Pool collapsed in March 1968, rekindling fears for the stability of the dollar. The FOMC voted to increase restraint at each of four consecutive meetings. In two of them, on March 14 and April 19, the decision was primarily for international reasons. The Fed raised the discount rate on March $22^{\text {nd }}$, April $19^{\text {th }}$ and December $12^{\text {th }}$. While the last increase, by 25 basis points, was motivated by the desire to counter inflation, a larger increase of 50 basis points was rejected on this occasion because of fears of how the dollar would be affected were the British in the face of a large capital outflow to the U.S. to abandon their peg and float.

The minutes make clear what was motivating the FOMC. On March $5^{\text {th }}$ Mr. Brill of the Board of Governors staff observed that "[o]n balance, the package of a half-point increase in the discount rate and a quarter point increase in Reg Q ceilings [offers] the best hope for achieving fairly prompt financial restraint on expenditures and attracting favorable attention from foreign investors, without engendering a panic reaction among financial 
institutions and financial markets" (p.61). Hayes warned that "A moderate tightening effort should be favorably received abroad as a means of defending the dollar... Thus the present is an appropriate time for a policy move” (p.69). Mr.Coldwell, an alternate member of the FOMC, "thought [that] the country was moving toward a serious and perhaps critical juncture of destabilizing forces... wage price pressures were increasing...the balance of payments deficit showed no improvement and runs on the gold market were occurring with increasing frequency. The overall situation demanded restraint in monetary policy” (p.79).

At the FOMC meeting on March $14^{\text {th }}$, when the decision to suspend the operation of the London Gold Pool was announced to the committee, Mr. Coombs warned that "the international financial system was moving towards a crisis more dangerous than any since $1931 \ldots$.. [it was] important to protect the exchange parity network...based on the official price of $\$ 35.00$ per ounce for gold...or by making sure that the System swap lines were fully adequate to absorb the massive flows of hot money across the exchanges...” (p.4). The directive that day included the following: "In light of recent international financial developments, the System open market operations... should be conducted with a view to maintain firm but orderly conditions in the money market, taking into account the effects of the Federal Reserve discount rate” (p.5). The discount rate was then raised on March 22. At the meeting on April $2^{\text {nd }}, 1968$ Coombs warned that "the breakdown of the gold pool was... a major defeat for the central banks and governments involved... the system was now considerably more vulnerable than before...” According to Robert Solomon (associate economist at the Board of Governors), "[t]he gold pool supplied gold to private speculators in order to forestall a run on the dollar by official holders... But the gold pool 
policy ...designed to maintain credibility in the official price of gold...itself lost credibility...”[a] much less happy scenario assumes that inflation continues in the US and [the trade balance worsens]...In this unhappy scenario, the world begins to believe that the U.S. balance of payments deficit cannot be reduced without drastic measures involving ...[a] change in the relationship between the dollar and gold... To prevent monetary chaos and to assure [a] more favorable evolution, the U.S. must improve its trade balance... both domestic and international considerations call for restrictive monetary policy” (p.15-16).

Brill voiced similar fears: "Our international payments position is more precarious, and inaction is proceeding more rapidly than we had estimated even just a month ago...It seems to me...that we would be warranted in changing our sights on what is required of monetary policy....there seems to be a sufficiently strong argument for turning the monetary screws a bit more this time” (p.42). Hayes predictably agreed: "Although we have lived through a major financial crisis since our last regular meeting...the basic facts that should determine monetary policy have changed relatively little in that period. The crisis did...point up in a most dramatic fashion the perilous position of the dollar reflecting the current problems of inflation, lack of fiscal responsibility, and payment imbalances... my preference with respect to open market policy would be to move very gradually toward even further restraint... The proposed policy will lead to a modest firming of the market interest rate and to expectations of another discount rate rise... we should be contemplating the possibility of another one half point increase in the discount rate sometime before the end of April, when even keel restraint will commence so as to make crystal clear the System's determination to do what it reasonably can to uphold the dollar's international 
standing” (p.47-49). According to Mr. Bopp, an alternate member of the FOMC, "further tightening would confirm that the committee meant business, and that was necessary for both international and domestic reasons" (p.57). Mr. Daane agreed that "greater monetary restraint in the U.S. was necessary to support the decision at the recent meetings in Washington [where the two tier gold policy was agreed] and Stockholm [where provisional agreement was reached to issue Special Drawing Rights]...he would be quite amenable to another increase in the discount rate...” (p.69-70). The discount rate was raised by 50 basis points on April 19th.

But this was not enough to dispatch the problem. At the meeting on May $28^{\text {th }}, 1968$, Brill stated that " $[\mathrm{t}]$ he most urgent need would be associated with our international financial problem...the main hope for keeping...in place...existing international financial arrangements lies in the promise that measures of restraint here will convince other countries that we are serious about our intention to curb inflation...” (p.48). At the meeting on December $17^{\text {th }}, 1968 \mathrm{Mr}$. Hersey, an associate economist at the Board of Governors, urged the Committee "to give full consideration to the long-run problem of checking inflation and halting the deterioration of the international trading position... The principal contribution that monetary policy can make to the defense of our external financial position is through stability of the price level ... monetary policy aimed at slowing inflation will bring higher interest rates... it is the slowing of inflation that is most needed for dealing with the balance of payments problem, not higher interest rates per se” (p.43). The discount rate was raised on December $18^{\text {th }}, 1968$, preventing any further deterioration in the external situation through the end of 1968. 
The Nixon Administration, taking office in January 1969, inherited inflation from the previous administration but, rather than urging a tightening monetary policy, attempted to deal with the problem with wage price guidelines and later wage-price controls. There also was widespread discussion of the possibility of floating the dollar in response to the chronic balance of payments deficit and loss of gold reserves. Arthur Burns, who became Chairman of the Federal Reserve in February 1970, viewed such international considerations as primarily Treasury’s problem.

A long period followed when there was limited discussion of balance of payments problems. In 1971, the problem then resurfaced a final time. In the April $6^{\text {th }}, 1971$ FOMC meeting, the vote was for tightening. A minority led by Hayes wanted more tightening than the Committee was willing to vote for to defend the dollar - Hayes emphasized that "the international financial situation should be given a high priority in the FOMC's policy deliberations” (p.35) - but the majority was preoccupied by the precarious state of the economy. Chairman Burns saw grounds for optimism on the external front, though he remained cautious. "In the international area, he found it most encouraging that short-term interest rates in the U.S. and abroad were finally beginning to converge... He observed that the dollar had come under speculative pressure that had begun to reach dangerous proportions last week...the recovery was quite fragile, and economic conditions in general were at a delicate stage. He had a vivid recollection of 1931, when the Federal Reserve had raised its discount rate and acted to stiffen short- term rates because of a balance of payments problem, and an incipient recovery had been cut off...He concurred in the suggestion that short-term rates should now be permitted to move up a little further..” 
(p.56). Hayes, predictably, was more alarmist, warning that “...on the international side we seem to be moving into the kind of major crisis that has long loomed as a probability in the light of our huge payments deficit, especially on the official settlements basis; and the sharp contrast between interest rates here and abroad. Under these circumstances I think we should promote a firming of short-term interest rates to the extent this can be accepted without causing major repercussions in the bond market” (p.57). Hayes concluded that he found it "necessary to dissent from the proposed directive, which he thought gave inadequate recognition to the need for moving toward somewhat higher short-term interest rates in light of the international financial situation” (p.83).

At the May $11^{\text {th }}$ meeting, the FOMC voted for increased restraint because of concern over the international situation, although it rejected the 50 basis point rise in the discount rate requested by the New York Fed, citing concerns over the weakness of growth. The Chairman summarized the situation. “Toward the end of last month one Reserve Bank [New York] had proposed a discount rate increase of one-half point. The Board had voted to disapprove the increase for the following reasons. 1....it was concerned about the effects on debt markets, which were in a highly sensitive condition. 2....with the economic recovery still fragile, a discount rate increase could damage confidence. 3. The Board feared a rise in the discount rate might have a significant impact on long-term interest rates” (p.52).

Hayes, predictably, disagreed. “Last Thursday our directors voted unanimously to raise the discount rate by one half per cent to $5 \frac{1}{4} \%$. They recognized that under ordinary circumstances such a move would not be desirable, coming just after a Treasury refunding 
operation. They also recognized that the usual sequence in working toward a firmer monetary policy would be to start with open market operations and to use the discount rate as a confirming action. Finally they were aware that a $1 \frac{1}{2} \%$ discount rate increase could have substantial unsettling effects on the delicately poised bond market. Nevertheless, the directors felt that in this major international crisis there was nothing the System could do that could be more useful and more timely than to give an overt signal of our concern and our willingness to move quickly toward narrowing the interest rate spread which was a major cause of the difficulty.... They felt that prompt action on the discount rate serves as an important signal both to authorities in Germany and other countries that were in the process of making crucial decisions, and to the unsettled foreign exchange market that the U.S. intended to defend the value of the dollar while recognizing the risks involved in a general increase in domestic interest rates, they felt that these risks were outweighed by international considerations, more particularly against the background of rapid growth in money and credit aggregates... I regret that the Board was not willing to approve the increase last week. But it is still not too late to move, and a discount rate increase might well play an important role in the eventual resolution of the exchange market problem” (p.56). His arguments registered. In June, to defend the dollar the System raised the discount rate by 25 basis points. This was followed by a 50 basis point rise in the Federal funds rate in July.

In the last meeting before the end of the dollar peg on July $27^{\text {th }}$, 1971 , Hayes and the other members, while voting for increased restraint and acknowledging the seriousness of the situation, were reluctant to apply additional monetary restraint owing to concern for the 
domestic economy. Instead they pinned their hopes on incomes policy and other measures including the tariff surcharge to strengthen the balance of payments. To Hayes it seemed clear that "the U.S. balance of trade and the overall balance of payments were in an especially critical state...” (р.32). "The firming of short-term interest rates that has already occurred has...helped in a major way, along with some interest declines abroad, in checking the interest induced short-run capital flow that paved the way for the May currency crisis. While further firming of the money market might bring some additional benefit in this area, I think that for domestic reasons we have done about all we can afford to do at the moment in the monetary field for the balance of payments and by way of a control to combating inflation psychology. We cannot overlook the fact that the economic recovery is still rather fragile and that unemployment seems likely to drop only slowly over the coming year ... my willingness to hold still on monetary policy in no sense implies the absence of great concern over the prospects for containing inflation and a drastically unsatisfactory balance of payments position. These conditions underlie the urgent need for an effective incomes policy. I also believe the time is ripe for a hard look at a new "package” approach to ways of reducing our international payments deficit” (p.55-56). With monetary policy sidelined, the pressure on the dollar could not be contained. On August 15th, facing the prospect of massive Western European conversion of outstanding dollar balances into gold, President Nixon closed the gold window, effectively ending the Bretton Woods System.

Thus, we also see in this second period sporadic mention in the minutes of the stability of the dollar and balance of payments concerns. However, these issues arose at 
longer intervals. Not only were they more widely separated in time, but one can see an even more explicit balancing in the statements of FOMC members of the need to defend the dollar against the need to support economic activity. This reflected the growing importance attached to stimulating output and employment not just within the Fed but in the Treasury and the Administrative Branch more generally. But it also reflected the perception that primary responsibility for dealing with the dollar crisis had been assumed by the Treasury, which would deploy an ever widening array of non-monetary instruments in the effort to resolve it.

\section{Quantitative Evidence}

Quantitative evidence can lend support to our view by showing that the Fed's commitment to defense of the dollar helped to anchor inflation through 1965. We show that monetary policy was even tighter in this period than concern with inflation and the domestic economy alone would predict, suggesting a role for factors like the weakness of the balance of payments. We show that inflation was less persistent and that expectations were better anchored than subsequently. The evidence points to a break in 1965 at the time when balance-of-payments considerations stopped figuring as prominently in the calculus of the FOMC.

In Figure 2 we show the Fed's monetary policy rule as calibrated by Taylor (1999). ${ }^{19}$ We combined his parameters with data on inflation and on the output gap

\footnotetext{
${ }^{19}$ We also estimated our own version of the Taylor rule using the forward looking approach of Romer and Romer (2002), focusing on the period 1959-Q1 - 1971-Q3. Romer and Romer evaluated Federal Reserve policy in the 1950s. They estimated the forward looking Taylor Rule in the manner of Clarida, Gali and
} 
measured using measured real GDP less the most recent Bureau of Economic Analysis estimates of potential real GDP. In addition we calculate a Taylor Rule using Orphanides’ (2003) real time data on the output gap (using data from the original Bureau of Economic Analysis sources, not data as subsequently revised, which is arguably appropriate as indicating what policy makers focused on at the time).

As can be seen, before 1965 policy was even tighter than would be expected on the basis of inflation and the output gap alone. The difference is minor when we calculate the output gap mechanically but quite dramatic when using Orphanides’ method. Thereafter, policy is generally looser than expected, dramatically so when we use a simple measure of the output gap but more modestly when using Orphanides’ approach.

Figure 3 shows three measures of inflation and inflation persistence: the percentage change in the CPI, in the GDP deflator, and in money wages. We plot the raw data in panel a and the serial correlation of inflation based on an AR (1) regression using a ten year rolling window in panel b. To correct for the bias that arises when persistence is estimated using OLS (Andrews 1993), we show the median unbiased estimator for each series in panel c. As can be seen from the rolling regression and median unbiased estimates, inflation persistence increased dramatically after 1965.

We also use statistical methods to estimate underlying inflation persistence and ask whether there is evidence of a shift around 1965. Like Cecchetti, Hooper, Kasman,

Gertler (2000), according to which the Federal Reserve chooses the federal funds rate in response to inflation and the deviation of output from trend. This method is forward looking in that the Federal Reserve is assumed to respond to expectations of the variables. The equation is estimated using instrumental variables, where the instruments are contemporaneous and two lags of inflation, and output deviations. We used two measures of the output gap; one based on BEA potential output; the other based on a Hodrick-Prescott trend of real GDP. The coefficient on inflation was statistically significant and close to one and satisfies the Taylor principle, while the coefficient on the output gap is quite small. 
Schoenholtz and Watson (2007), we use Stock and Watson’s (2002, 2006) smoothed estimator to construct estimates of the trend (permanent) and transitory components of inflation using nonlinear methods analogous to the Kalman filter. In the top panel of Figure 4 we separate inflation into a permanent or trend component and a transitory component. In the middle panel we show the first order autocorrelation of the change in U.S. inflation. This statistic summarizes the relative importance in the inflation process of the variances of the permanent and transitory components. The dotted line shows the break point at which the inflation process becomes persistent. Finally the bottom panel, for comparison shows two measures of external balance: the official settlements balance of payments deficit (surplus) and the current account deficit (surplus).

As can be seen from the upper panel of Figures 4.1 and 4.2, trend inflation follows actual inflation with a lag. Actual and trend inflation both rise in the mid-1960s, around the time of the shift in the locus of primary responsibility for managing the balance of payments. The calculated break in the inflation persistence process, in contrast, occurs in 1968, while the middle panel shows a steady pickup in the importance of the permanent component of inflation through the 1960s. The results for wages in Figure 4.3 are different from those on inflation. They show a much slower build up of inflationary momentum with the break in trend only coming in 1973.

Finally, there is evidence that these changes did not escape the attention of investors. In Figure 5 we show the Livingston survey of inflation expectations. ${ }^{20}$ While the series is volatile, there is a clear break in 1965, as one would expect on the basis of our analysis. ${ }^{21}$

\footnotetext{
${ }^{20}$ Data are from the website of the Federal Reserve Bank of Philadelphia.
} 
Even this limited empirical analysis confirms the complexity of the inflation process in the 1960s and early 1970s. Over time inflation accelerated, became more persistent, and exhibited greater volatility. There appear to have been a number of different break points depending on the aspect of the process under consideration: at or around 1965, at the end of the 1960s, and in the early 1970s. The break around 1965 is plausibly associated at least in part with the declining weight placed by the Fed in its policy decisions on the weakness of the balance of payments and the fragility of the dollar. The fact that monetary policy was even tighter in preceding years than one would expect on the basis of inflation and the output gap alone confirms that the Fed had been factoring in other considerations to its policy decisions, plausibly the balance-of-payments considerations described above.

\section{Conclusion}

Explanations for the acceleration of inflation in the late 1960s and early 1970s emphasize a growing tendency to characterize the inflation problem as unrelated to Federal Reserve policy (Romer and Romer 2002a, Nelson 2005), as resulting from an excessively stimulative or overly accommodating monetary policy that failed to take inflation control as its central focus (DeLong 1997, Clarida, Gali and Gertler 2000), and as reflecting a mistaken belief in an exploitable Phillips Curve tradeoff (Taylor 1992, Sargent 1999).

\footnotetext{
${ }^{21}$ In addition, there is the evidence of Chen and Giovannini (1992), who used a target zone framework to estimate the probability, implicit in forward exchange rates and interest differentials, that the dollar would be devalued against the deutschmark during the Bretton Woods period. They find essentially no perceived probability of dollar devaluation before 1965 but a growing probability in the second half of the Bretton Woods period. The problem with this test is that the deutschmark price of gold could also change if the German currency was revalued against the dollar, as it in fact was on a couple of occasions under Bretton Woods.
} 
There is insight in all of these interpretations. No account of the Great Inflation would be complete without them.

But neither would it be complete without recognition of the changing role of the external constraint in FOMC members' calculations. It is not as if it took until the end of the 1960s for the idea of an exploitable Phillips Curve tradeoff to come to Washington. Romer and Romer (2002) show that this idea was already being advanced by the Council of Economic Advisors in the early 1960s. It can be argued that much of the decade had to pass before the ideas pushed by the Council were internalized by the Fed. Or perhaps not until President Johnson gave William McChesney Martin his famous verbal lashing and bounced him around the LBJ ranch in a jeep did the Chairman disregard inflation as monetary policy’s central focus and accept an unrealistically low estimate of the natural rate. To repeat, we agree that there is something to these points.

But in addition the record suggests that adoption of these ideas was delayed and willingness to act on them was constrained by the responsibility that FOMC members felt for defending the dollar and strengthening the balance of payments. This was a shared responsibility of Treasury and the Fed, but one that the Fed took seriously in the first half of the 1960s. And so long as it did so, the temptation to inflate was restrained.

What changed in the course of the first half of the decade was application by Treasury, with the consent of Congress, of a series of fiscal measures like the Interest Equalization Tax intended to strengthen the balance of payments. This affected the Fed's thinking through two channels. First, Treasury’s activism encouraged the belief that another agency had assumed primary responsibility for managing the balance-of-payments 
problem - that the Fed was now entitled to delegate the task. Second, measures like the Interest Equalization Tax that placed sand in the wheels of international financial markets encouraged the Fed to believe that it could loosen monetary policy and allow inflation to rise without posing as immediate a threat to the dollar as before.

This is not the only set of considerations that distinguished monetary policy in the first and second half of the 1960s. But it is an important part of the story. The even more dramatic acceleration of inflation in the 1970s when the exchange rate constraint was removed entirely only reinforces the point. 
Figure 1. FOMC Policy Actions and Dissents from FOMC Policy Actions.

FOMC Policy Actions
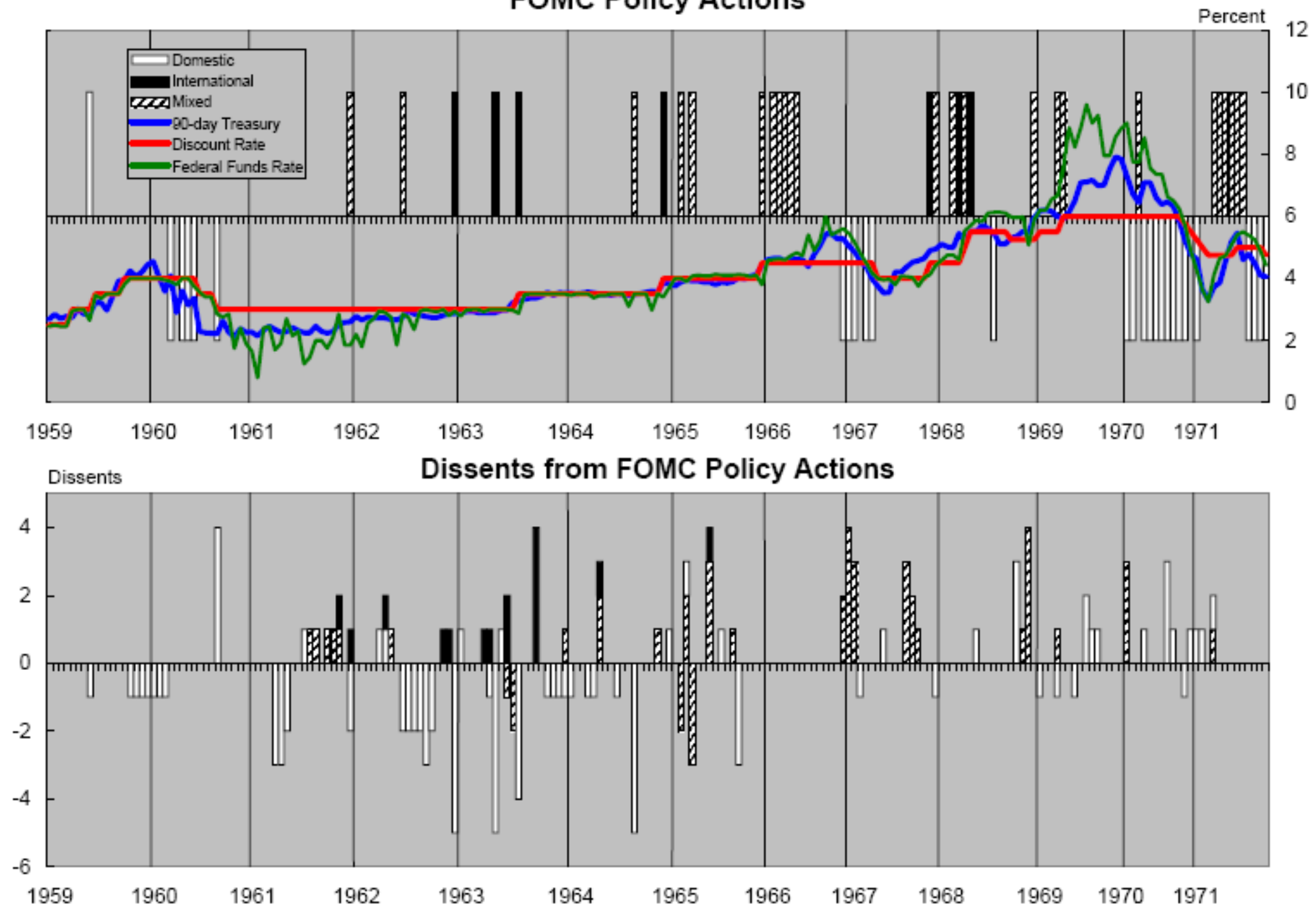
Figure 2. The Classic Taylor Rule

The Classic Taylor Rule

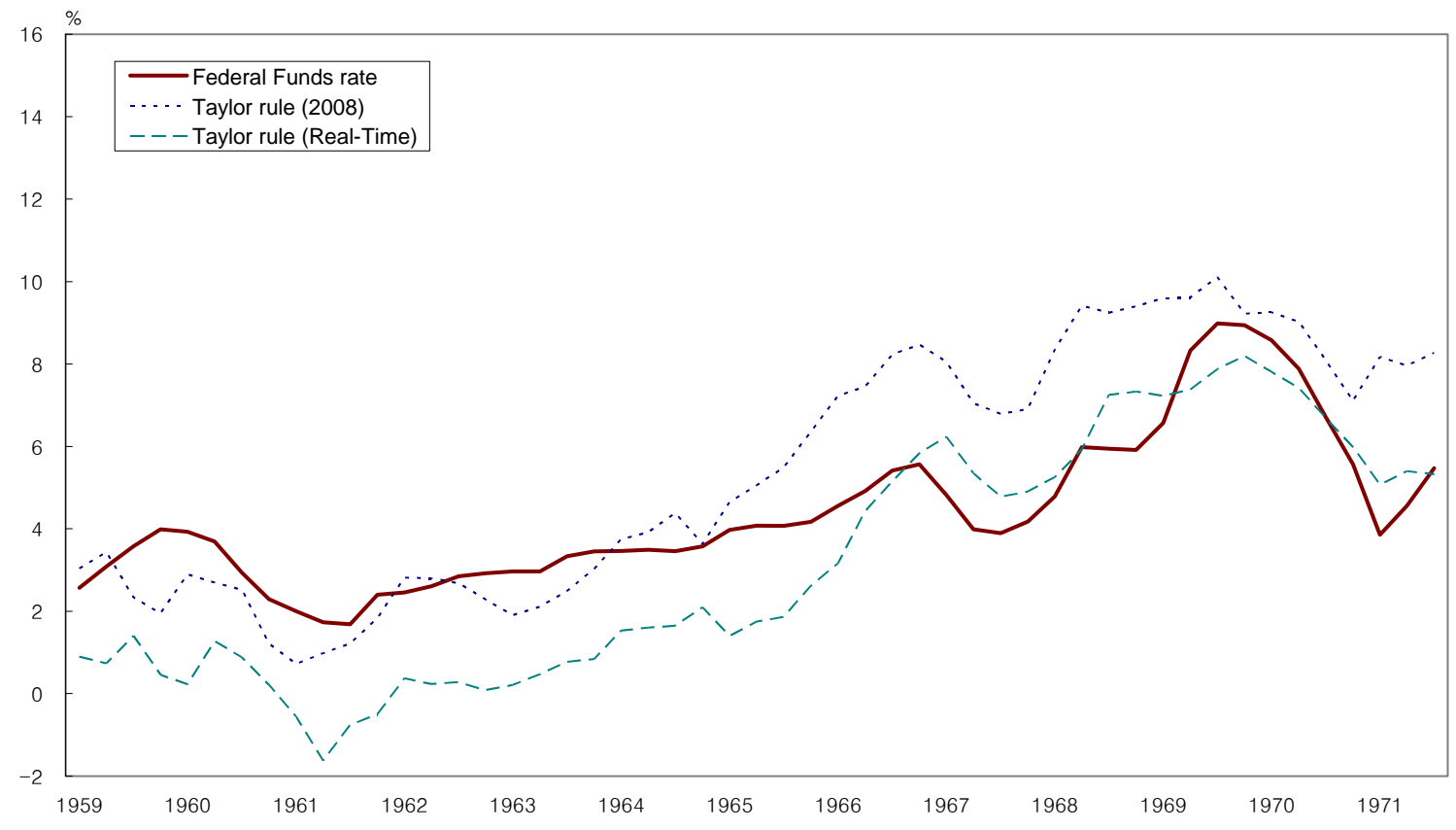


Figure 3. CPI Inflation and Inflation Persistence : G10, Quarterly data 1959 I to 1979 III

\subsection{US Inflation Rates : 1959 I to 1979 III}

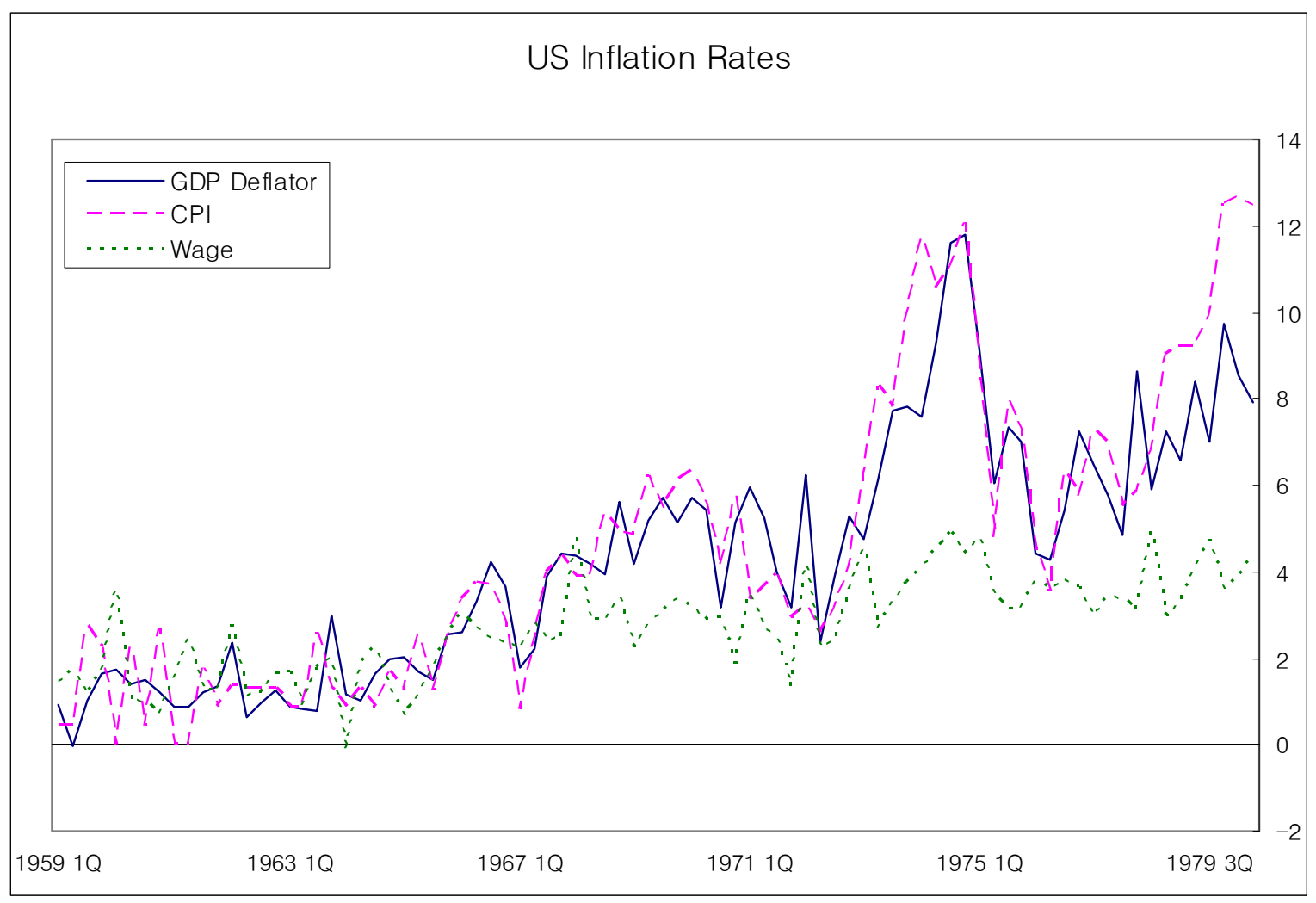

Data sources:

GDP deflator : Bureau of Economic Analysis, Department of Commerce CPI : Bureau of Labor Statistics, Department of Labor

Wage $=$ Nonfarm compensation per hour : Bureau of Labor Statistics, Department of Labor. 
3.2 US Serial Correlation of Inflation: 1959 I to 1979 III

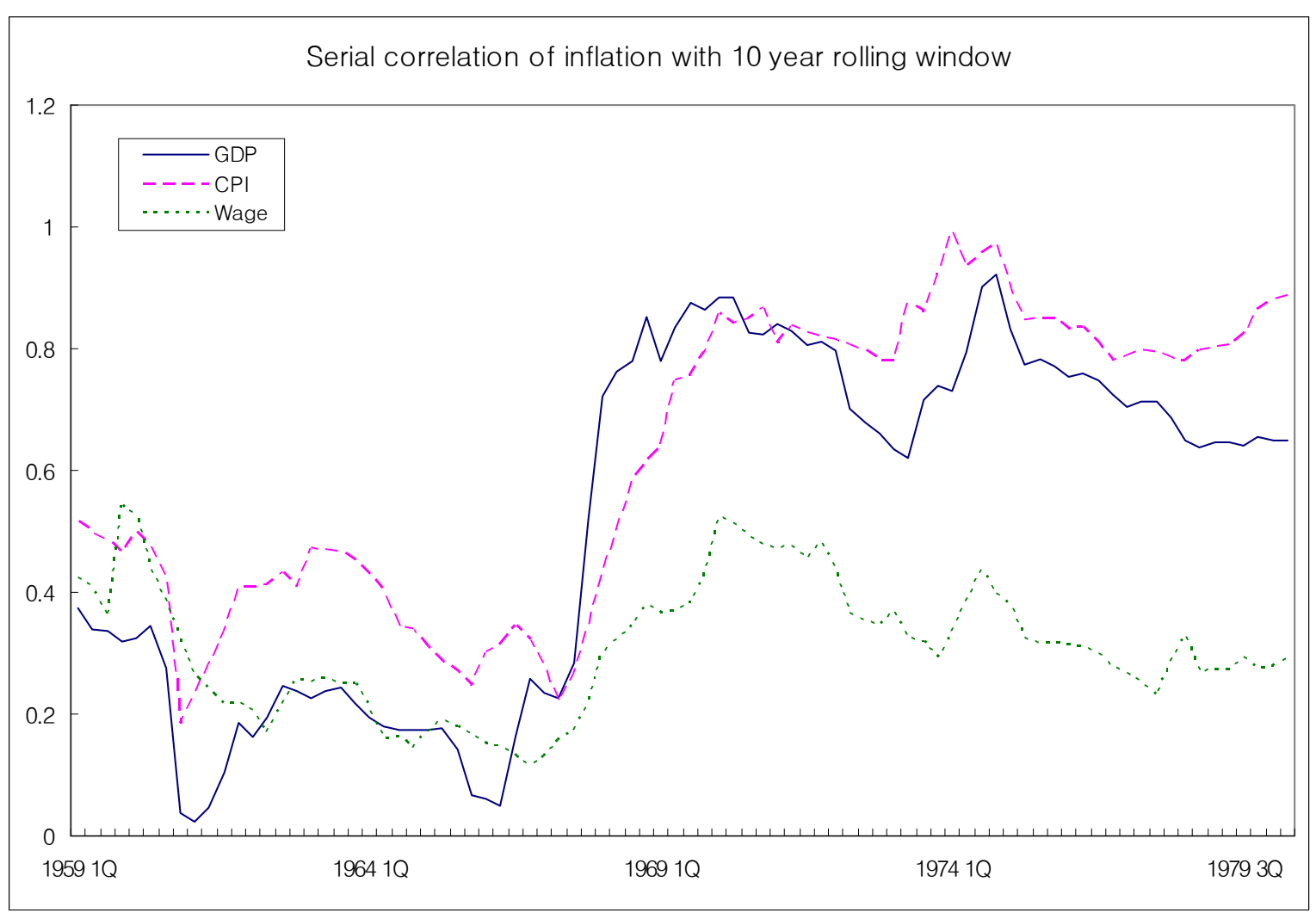




\subsection{US Median Unbiased Estimator for each series}

Model

$P_{t}=\bar{\mu}+\alpha P_{t-1}+U_{t}$ for $t=1, \ldots, T \quad$ where $\bar{\mu}=\mu(1-\alpha)$ and $\alpha \in(-1,1]$

where $P_{t}$ is the inflation rate of each series from Andrews(1993)

\subsubsection{GDP deflator}

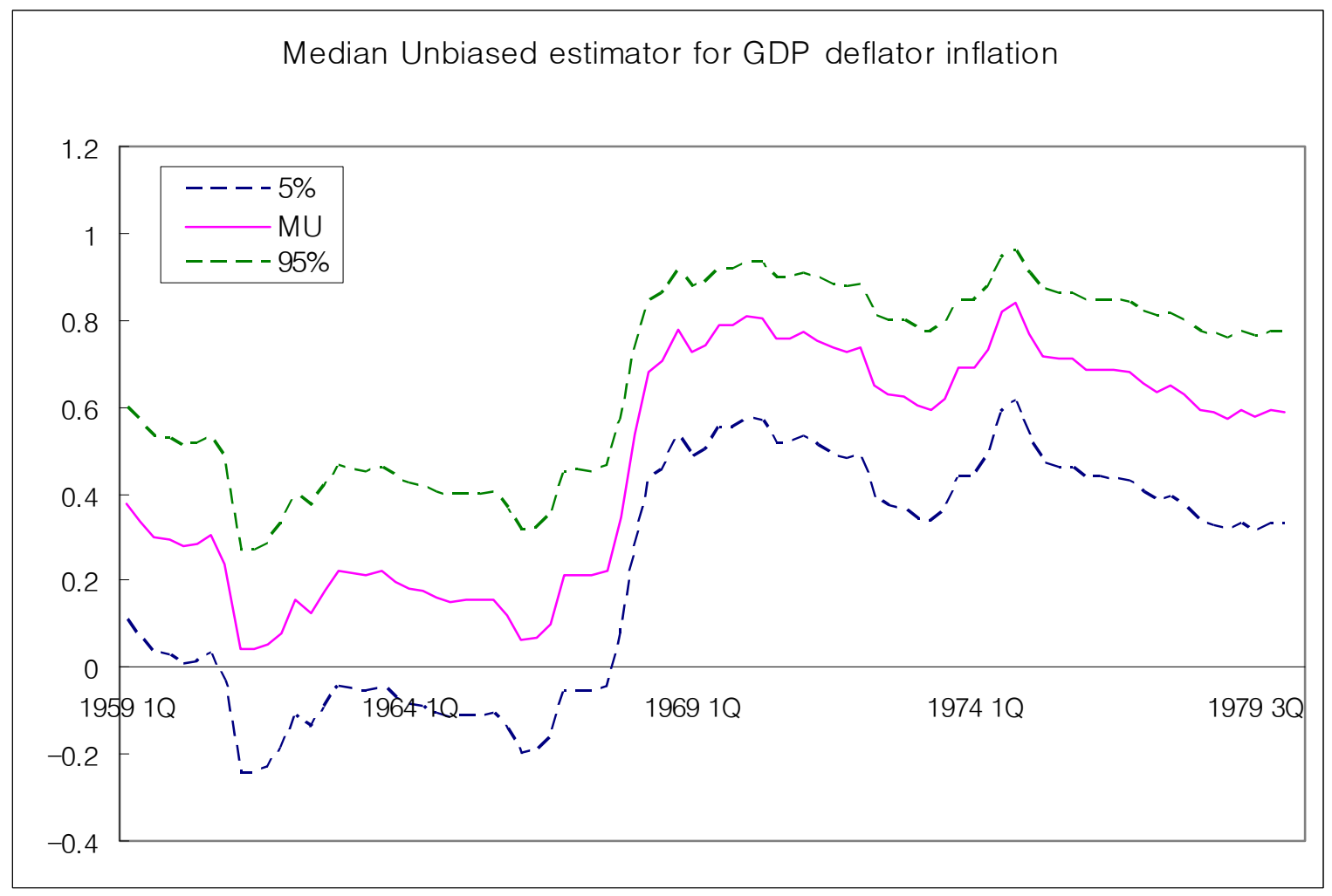




\subsubsection{CPI}

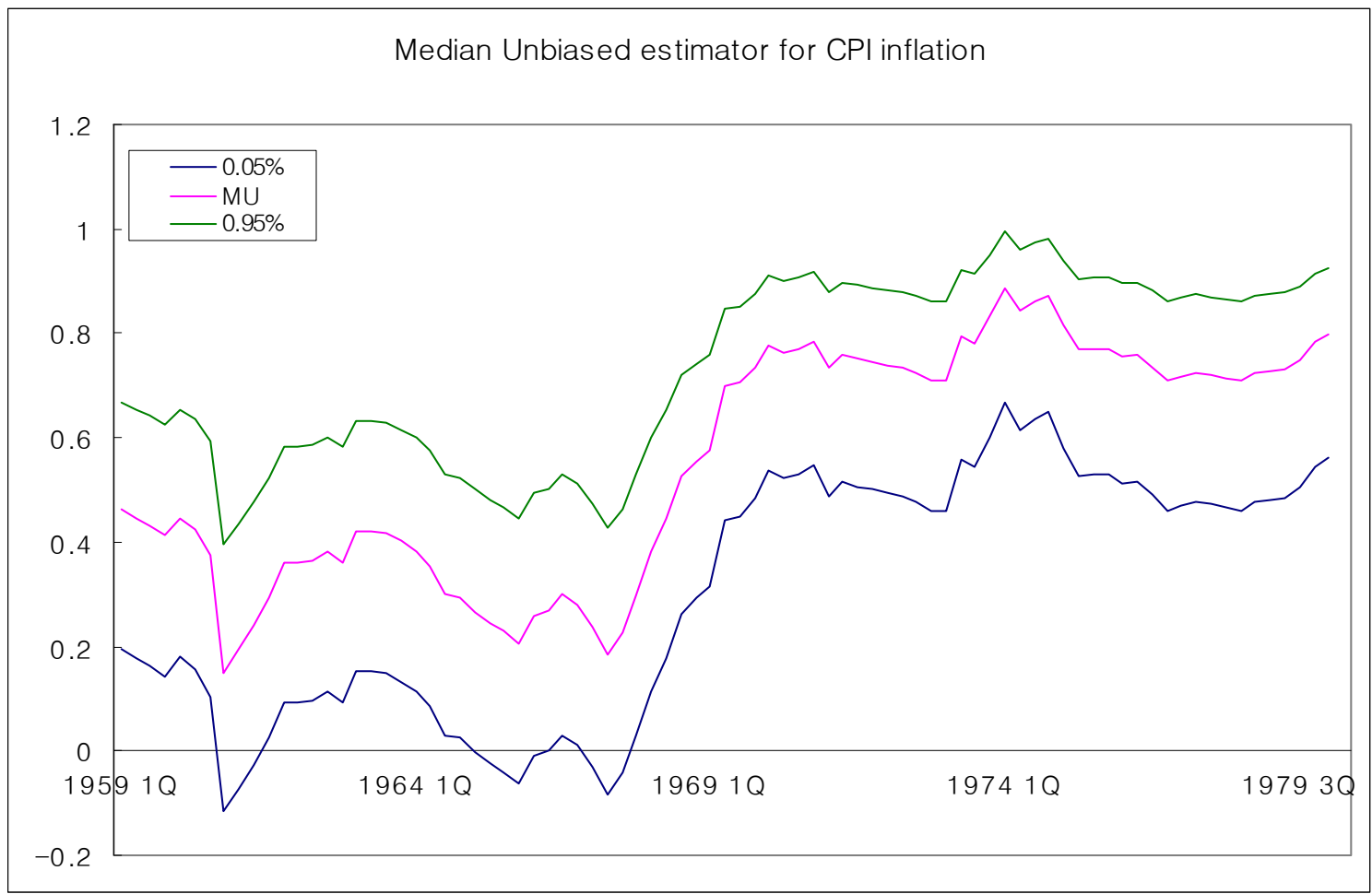

\subsubsection{Wage}

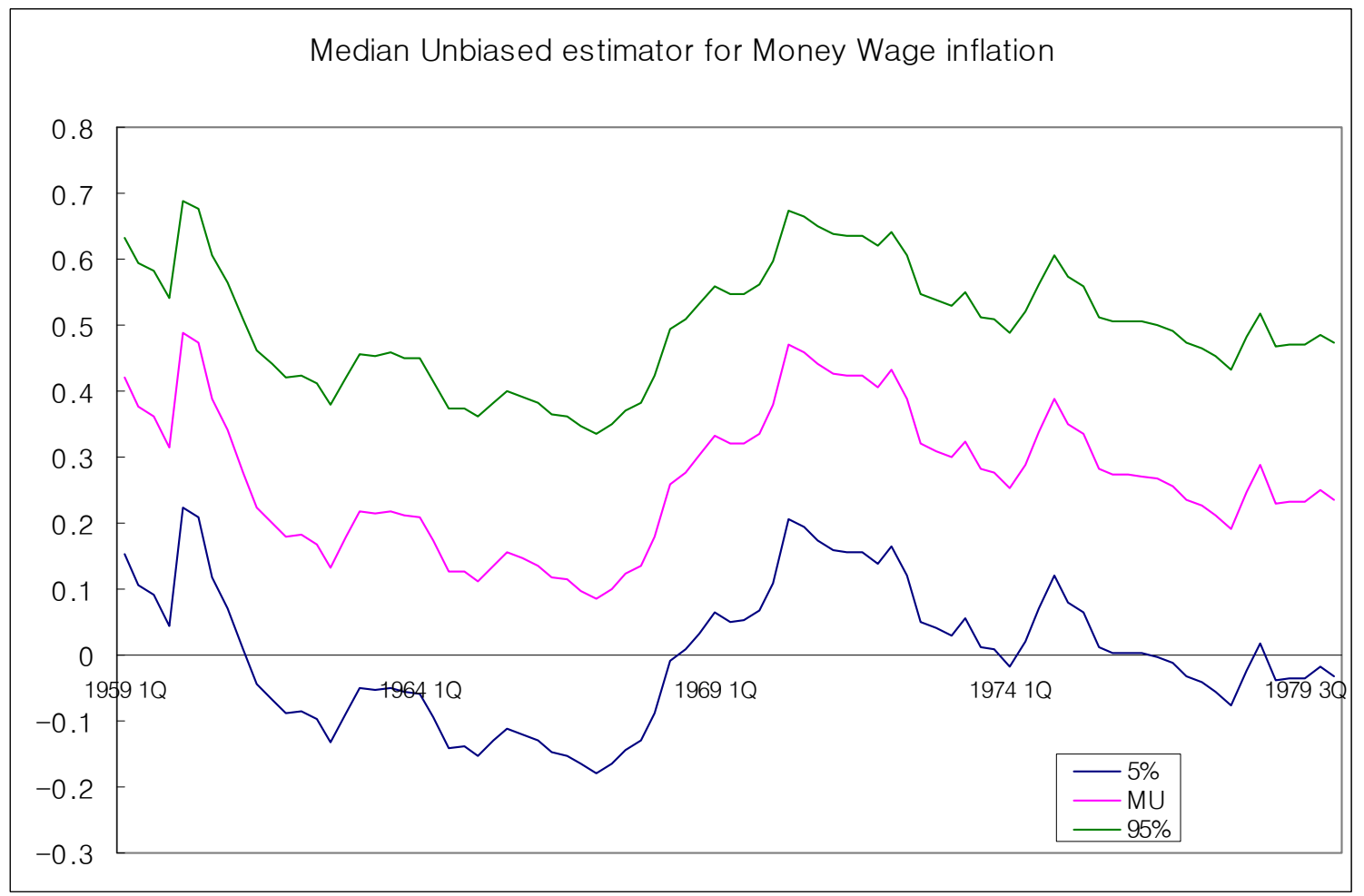


Figure 4.1 CPI Inflation, Inflation Persistence and the Balance of Payments 1959 I to 1979 III
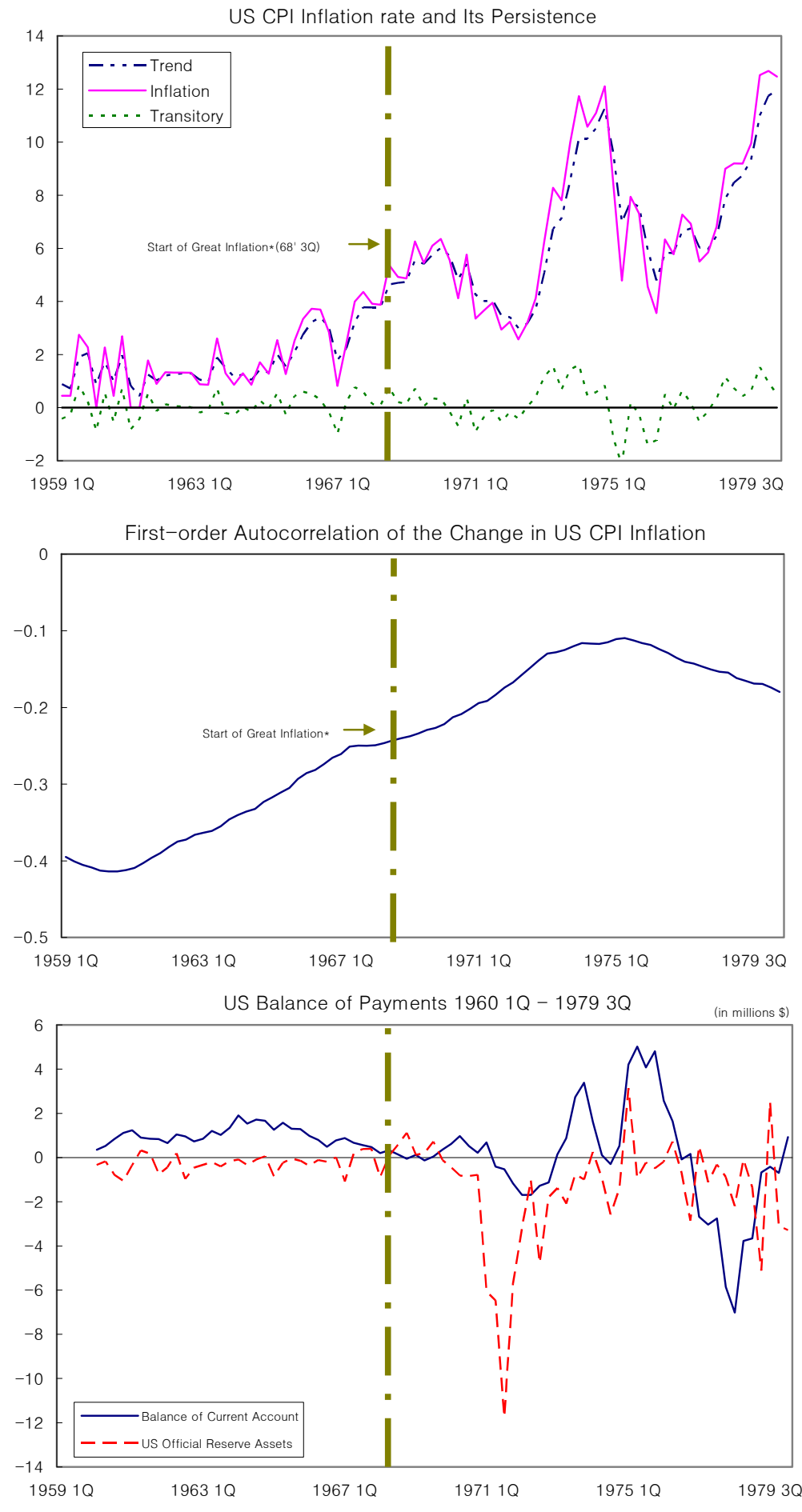

* Break generated from the trend of inflation greater than $4 \%$ 
Figure 4.2 GDP Inflation, Inflation Persistence and the Balance of Payments 1959 I to 1979 III

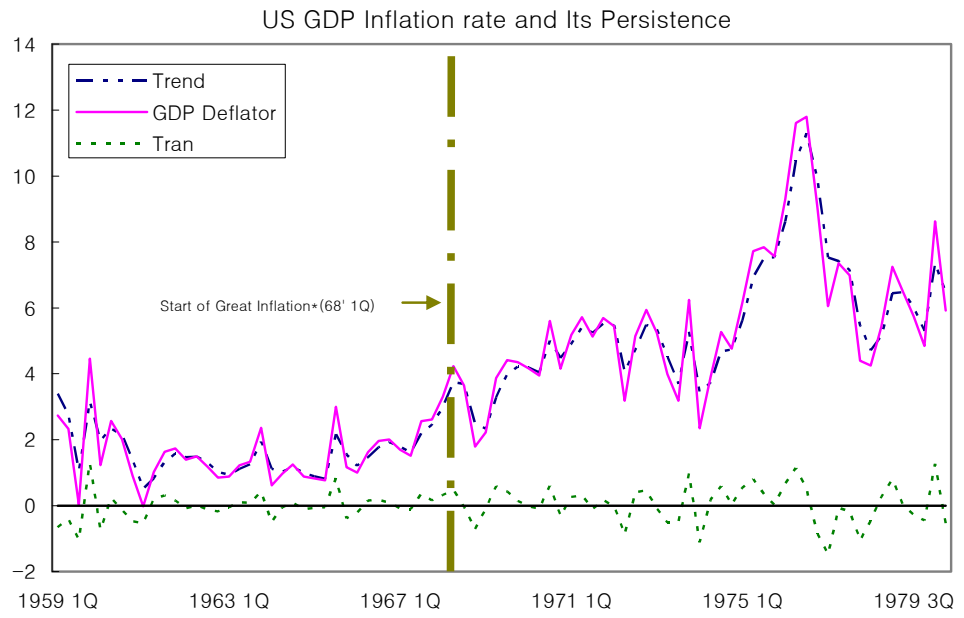

First-order Autocorrelation of the Change in US GDP Inflation
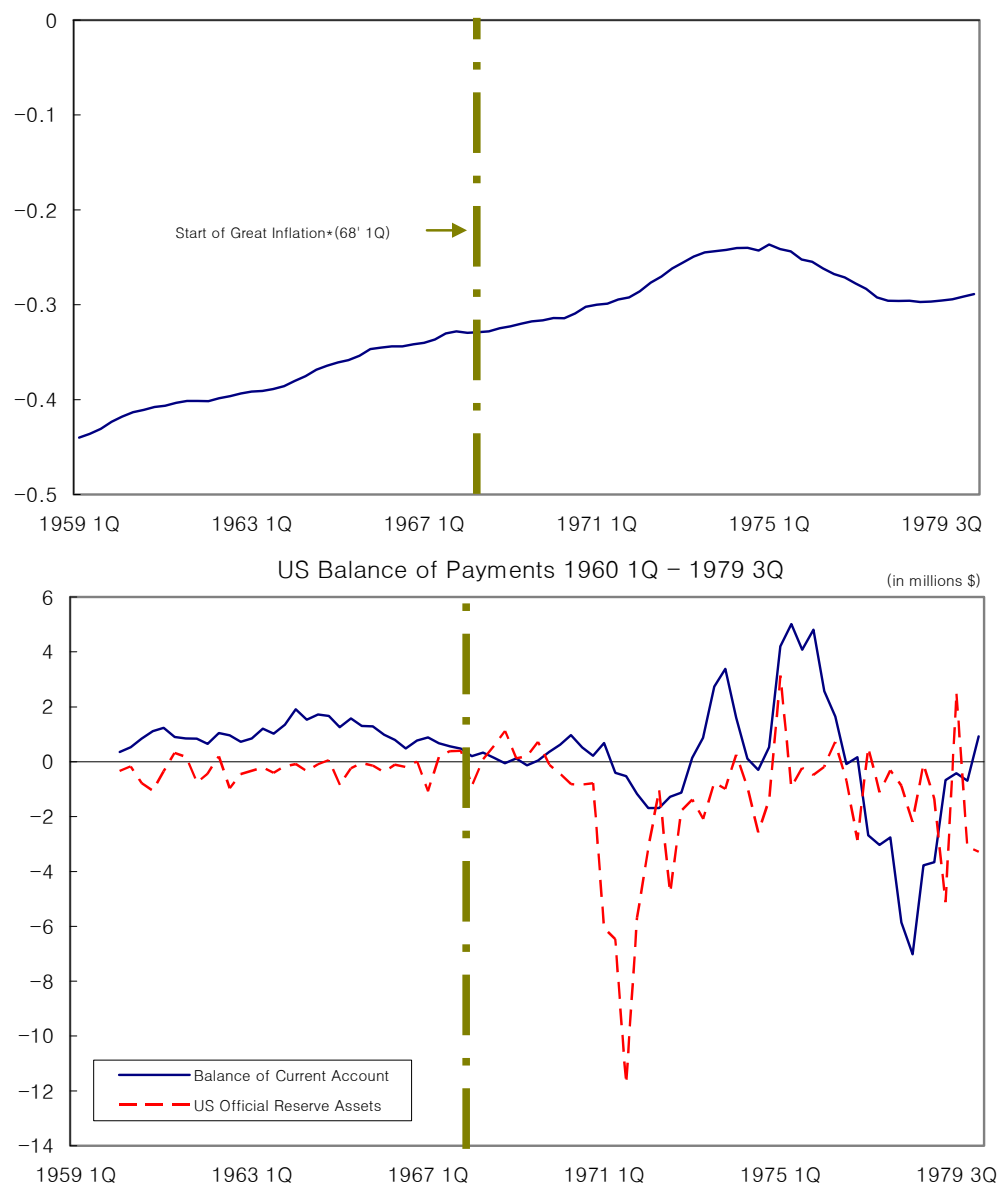

* Break generated from the trend of inflation greater than $4 \%$ 
Figure 4.3 Wage Inflation, Inflation Persistence and the Balance of Payments 1959I to 1979III
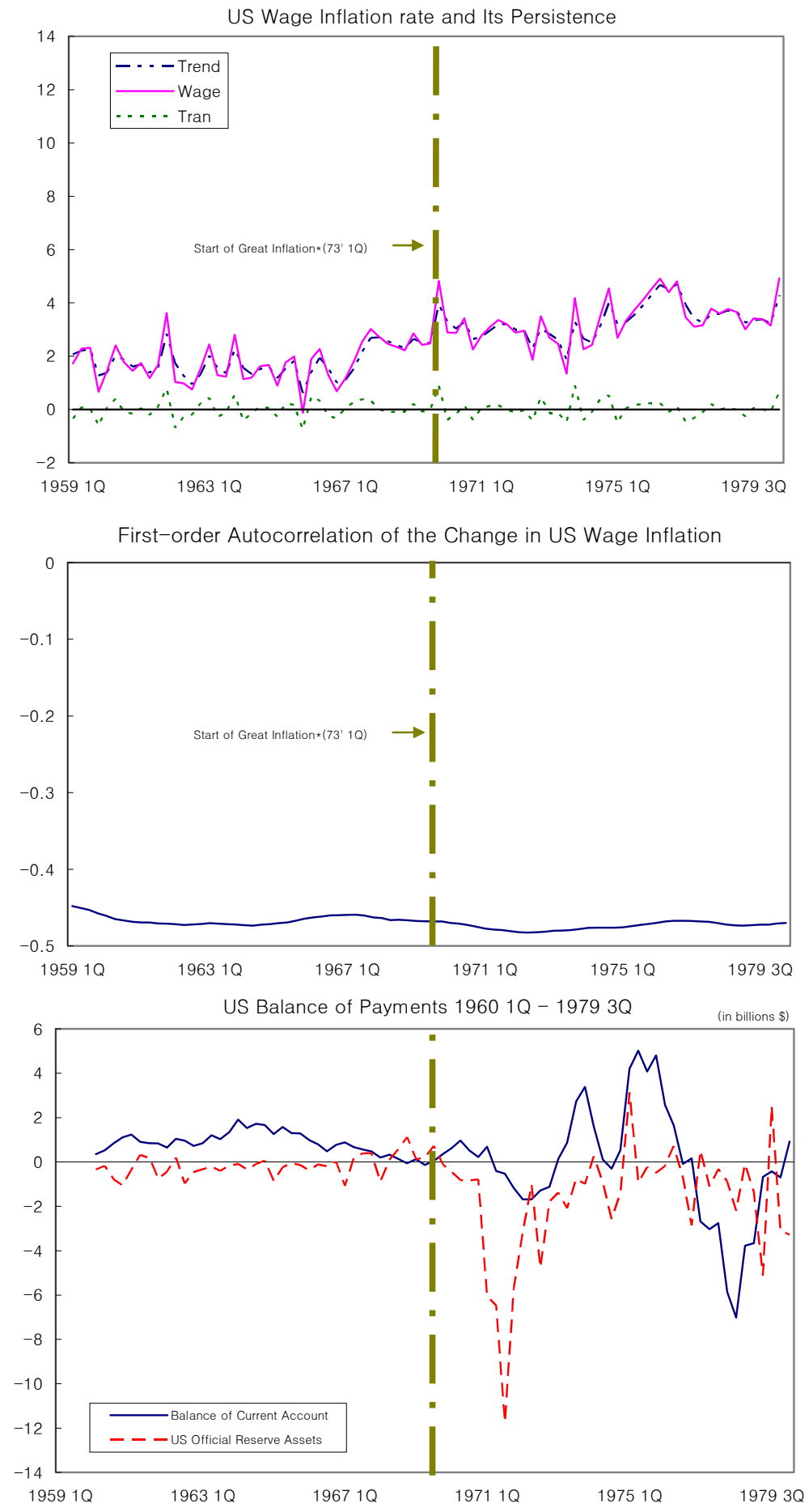

* Break generated from the trend of inflation greater than $4 \%$ 
Figure 5. The Livingston Survey 12 month forecast of inflation: 1959 to 1971

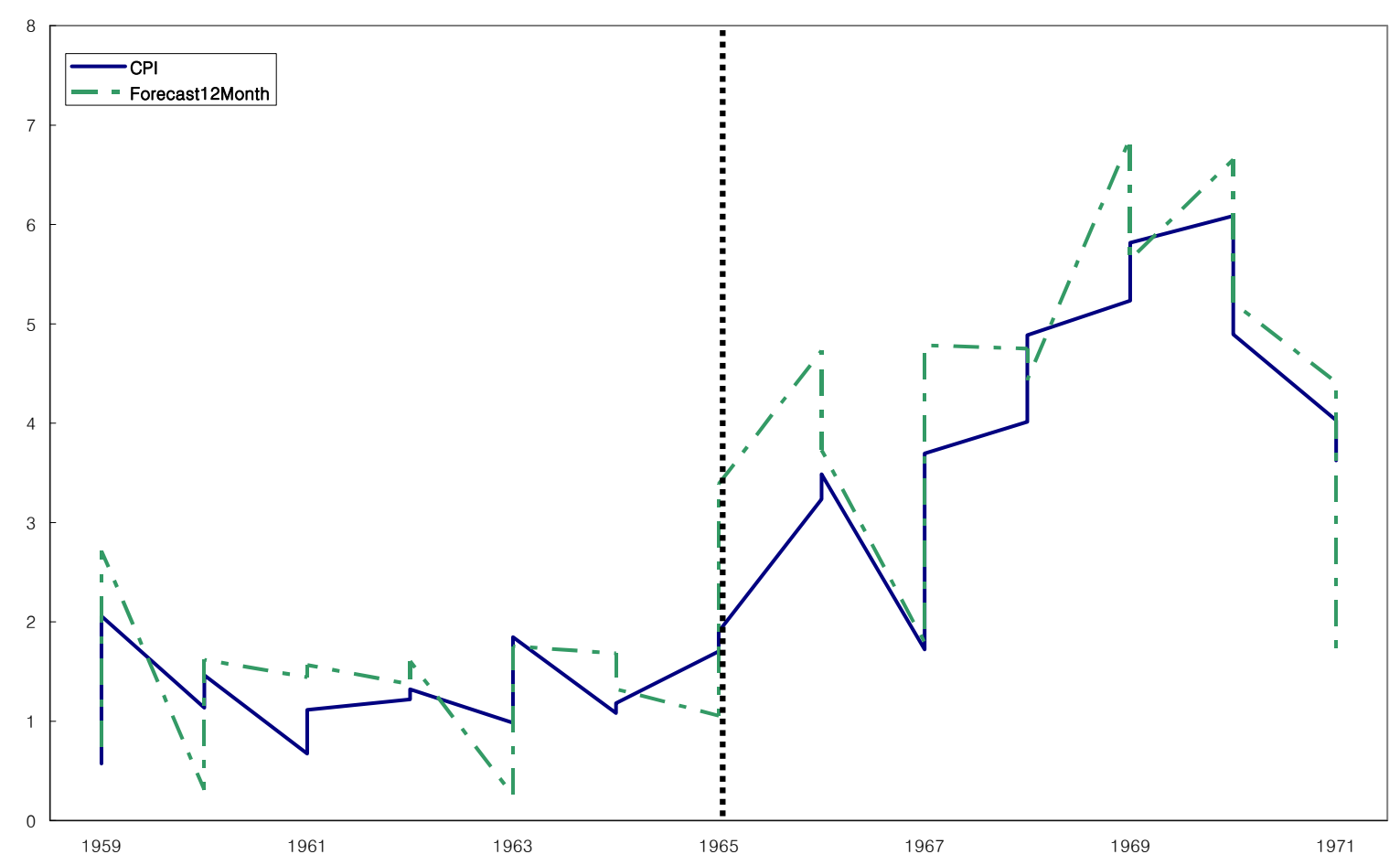




\section{Appendix 1. Nonmonetary Measures to Strengthen the Balance of Payments}

This appendix describes some of the nonmonetary measures pursued by the Treasury and the Administrative Branch in the 1960s with the goal of managing the balance of payments and strengthening the dollar. ${ }^{22}$

A first significant initiative was the Gold Pool, initially proposed by Treasury to foreign governments and accepted by the latter in October 1961. Central banks managed the pool on a day-to-day basis, operating as a gold sales consortium in the effort to stabilize the dollar price of gold and limit U.S. gold losses. The United States contributed 50 per cent of the resources of the pool, while four large European countries - the United Kingdom, France, Germany and Italy - contributed about ten per cent each and three smaller Europeans - Belgium, the Netherlands and Switzerland - kicked in about three per cent each. The idea was that when there was demand on the London gold market for gold at more than $\$ 35$ an ounce, creating an incentive for foreign official purchasers to convert their dollars into gold in the United States, the price would be pushed back down by the consortium of central banks, sharing the burden in this fashion, and not simply by the Federal Reserve acting as agent of the Treasury.

The Gold Pool never worked perfectly. There was a tendency for foreign central banks to replenish their gold reserves by converting dollars into gold after selling gold into the market. The arrangement broke down entirely after 1968. But so long as it operated, it encouraged the belief that U.S. gold losses would be limited.

\footnotetext{
${ }^{22}$ The account here draws on Meltzer (1991) and Eichengreen (2000).
} 
A second notable initiative was the Interest Equalization Tax (IET) of 1963. The IET was designed to strengthen the dollar and balance of payments by discouraging longterm lending to foreign countries. A tax equal to a one per cent rate of interest was imposed in 1963 on foreign bonds sold in the United States. To the extent that it was effective, this loosened the link between domestic and foreign interest rates and therefore the impact on the balance of payments of expansionary monetary policy. However, bank loans could be substituted for bonds - in response to which the tax was extended in 1965 to bank loans to foreigners with a maturity of more than one year. Short-term credits could be extended and rolled over as a substitute for long-term commitments. Some authors (e.g. Meltzer 1991) conclude that the IET, even as augmented, had relatively little effect, although others (e.g. Obstfeld 1993) point to them as explaining the magnitude of U.S.foreign interest differentials. But what matters from the present point of view is what policy makers likely believed regarding its effectiveness, and presumably such measures would have not been imposed had there been no confidence in their effectiveness.

A third initiative was to tie U.S. foreign aid. New aid commitments in the early 1960s were limited to countries that agreed to spend the dollars they thereby received in the United States. U.S. commitments to the Inter-American Development Bank’s Fund for Special Operations were similarly made subject to restrictions that made it difficult to use them except for purchasing U.S. merchandise. Measures such as these are estimated to have doubled the share of U.S. aid spent on American goods over the first half of the 1960s.

The Kennedy and Johnson Administrations adopted a series of initiatives designed to limit U.S. defense spending abroad. In 1962 the Defense Department instituted a Buy 
American program in which preference was given to American suppliers even when their goods were as much as 50 per cent more expensive than substitutes that might be procured abroad. Simultaneously with the announcement of the Interest Equalization Tax, it was announced that defense spending abroad would be reduced by $\$ 1$ billion. Foreign governments were pressured to buy U.S. military hardware as their quid pro quo for the stationing of American troops abroad.

Then there were various and sundry export-promotion initiatives. In 1963, for example, the White House held a conference on export expansion, at which the President and cabinet officials spent more than three hours exhorting business to sell more products abroad. Instances of such exhortation became commonplace in subsequent years. Finally, in 1965 the Johnson Administration negotiated a series of voluntary agreements with U.S. corporations designed to limit their foreign purchases and investment commitments. Each company was asked to submit a corporate balance of payments account and to indicate what steps it was taking to improve its balance by 15 to 20 per cent. Companies were then asked to commit to further improving in their corporate balances of payments in 1966. From 1968 the program was made mandatory and administered by the Office of Foreign Direct Investment. This initiative was also applied to U.S. banks. Individual banks were asked to ensure that their foreign lending as of end-1965 did not exceed end-1964 levels by more than 5 per cent. A similar ceiling was set for end-1966 lending, this time at 109 per cent of end-1964 levels. From 1966, nonbank financial institutions were also requested to limit the rate of growth of their foreign investments. 


\section{Appendix 2. FOMC Policy Actions}

\begin{tabular}{|c|c|c|c|c|c|c|c|c|c|c|c|c|c|c|}
\hline \multirow[b]{2}{*}{ Date } & \multirow[b]{2}{*}{ Meeting } & \multicolumn{2}{|c|}{ Attendance } & \multirow[b]{2}{*}{ Absent } & \multirow[b]{2}{*}{ Vote } & \multirow[b]{2}{*}{ Even Keel } & \multirow[b]{2}{*}{ Policy Decision at Meeting } & \multicolumn{2}{|c|}{ Reason for Directive } & \multirow[b]{2}{*}{ Total Dissents } & \multicolumn{4}{|c|}{ Direction of Dissent } \\
\hline & & \begin{tabular}{|l} 
Governors \\
\end{tabular} & President & & & & & \begin{tabular}{|l|} 
Domestic \\
\end{tabular} & International & & \begin{tabular}{|l|} 
Maintain \\
\end{tabular} & Ease & \begin{tabular}{|l|} 
Tighten \\
\end{tabular} & Non-Mon \\
\hline $\begin{array}{l}1 / 6 / 1959 \\
\end{array}$ & 1 & 5 & 5 & King (G), Shepardson (G) & $10-0$ & Yes & Maintain & 1 & 0 & 0 & -- & -- & -- & $-\ldots$ \\
\hline $1 / 27 / 1959$ & 2 & 6 & 5 & King $(G)$ & $11-0$ & Yes & Maintain & 1 & 0 & 0 & - & -- & -- & - \\
\hline $2 / 10 / 1959$ & 3 & 5 & 5 & King (G), Mills (G) & $10-0$ & Yes & Maintain & 1 & 0 & 0 & - & -- & -- & -- \\
\hline $3 / 3 / 1959$ & 4 & 6 & 5 & King (G) & $11-0$ & -- & Maintain & 1 & 0 & 0 & - & -- & -- & -- \\
\hline $3 / 24 / 1959$ & 5 & 5 & 5 & King (G), Martin (G) & $10-0$ & Yes & Maintain & 1 & 0 & 0 & - & -- & -- & - \\
\hline $4 / 14 / 1959$ & 6 & 6 & 5 & Martin (G) & $10-0$ & Yes & Maintain & 1 & 0 & 0 & -- & -- & -- & -- \\
\hline $5 / 5 / 1959$ & 7 & 6 & 5 & Martin (G) & 11-0 & Yes & Maintain & 1 & 0 & 0 & -- & -- & -- & -- \\
\hline $5 / 26 / 1959$ & 8 & 7 & 5 & & 11-1 & $\ldots$ & Increase restraint & 1 & 0 & 1 & 1 & -- & -- & -- \\
\hline $6 / 16 / 1959$ & 9 & 4 & 5 & Martin (G), Mills (G), Balderston (G) & \begin{tabular}{|l|l|}
$9-0$ \\
\end{tabular} & Yes & Maintain & 1 & 0 & 0 & - & -- & -- & - \\
\hline $7 / 7 / 1959$ & 10 & 6 & 5 & Robertson (G) & $11-0$ & Yes & Maintain & 1 & 0 & 0 & -- & -- & -- & -- \\
\hline $7 / 28 / 1959$ & 11 & 5 & 5 & King (G), Szymczak (G) & $10-0$ & Yes & Maintain & 1 & 1 & 0 & -- & -- & -- & -. \\
\hline $8 / 18 / 1959$ & 12 & 5 & 5 & Roberston (G), Shepardson (G) & $10-0$ & - & Maintain & 1 & 0 & 0 & - & -- & -- & - \\
\hline $9 / 1 / 1959$ & 13 & 7 & 5 & $\ldots$ & $12-0$ & -- & Maintain & 1 & 0 & 0 & -- & -- & -- & -- \\
\hline $9 / 22 / 1959$ & 14 & 7 & 5 & -. & $12-0$ & -- & Maintain & 1 & 0 & 0 & - & -- & -- & -- \\
\hline $10 / 13 / 1959$ & 15 & 7 & 4 & Johns (STL) & $11-0$ & -- & Maintain & 1 & 0 & 1 & -- & 1 & -- & -- \\
\hline $11 / 4 / 1959$ & 16 & $\frac{1}{6}$ & $\frac{4}{5}$ & Martin (G) & \begin{tabular}{|l|}
$10-1$ \\
1
\end{tabular} & -- & Maintain & 1 & 0 & $\frac{1}{1}$ & -- & 1 & -- & -- \\
\hline $11 / 24 / 1959$ & 17 & 6 & 5 & Balderston (G) & $10-1$ & Yes & Maintain & 1 & 0 & 1 & -- & 1 & -- & -- \\
\hline $12 / 15 / 1959$ & 18 & 7 & 5 & - & \begin{tabular}{|l|l|}
$11-1$ \\
\end{tabular} & Yes & Maintain & 1 & 0 & 1 & - & 1 & -- & - \\
\hline $1 / 12 / 1960$ & 1 & 7 & 5 & - & $11-1$ & -- & Maintain & 1 & 0 & 1 & - & 1 & -- & -- \\
\hline $1 / 26 / 1960$ & 2 & 7 & 5 & -- & $11-1$ & Yes & Maintain & 1 & 0 & 1 & -- & 1 & -- & -- \\
\hline $2 / 9 / 1960$ & 3 & 7 & 5 & $\ldots$ & 11-1 & $\ldots$ & Maintain & 1 & 0 & 1 & $\ldots$ & 1 & -- & $\ldots$ \\
\hline $3 / 1 / 1960$ & 4 & $\frac{1}{7}$ & $\frac{3}{5}$ & $\ddot{-}$ & $\mid \frac{11-1}{12-0}$ & -- & Decrease restraint & 1 & $\frac{0}{0}$ & $\ldots$ & 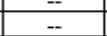 & $\ldots$ & -- & -- \\
\hline $3 / 22 / 1960$ & 5 & 6 & 5 & King (G) & $11-0$ & Yes & Maintain & 1 & 0 & -- & - & -- & -- & -- \\
\hline $4 / 12 / 1960$ & 6 & 6 & 5 & King & $11-0$ & -- & Decrease restraint & 1 & 0 & - & - & - & -- & - \\
\hline $5 / 3 / 1960$ & 7 & 6 & 5 & Mills & 11-0 & -- & Decrease restraint & 1 & 0 & -- & -- & -- & -- & -- \\
\hline $5 / 24 / 1960$ & 8 & 6 & 5 & Szymczak (G) & $11-0$ & -- & Decrease restraint & 1 & 0 & -- & -- & -- & -- & -- \\
\hline $6 / 14 / 1960$ & 9 & 6 & 5 & Shepardson (G) & $11-0$ & -- & Maintain & 1 & 0 & -- & -- & -- & -- & -- \\
\hline $7 / 6 / 1960$ & 10 & 7 & $\frac{5}{5}$ & - & $\mid 12-0$ & -- & Maintain & 1 & 0 & -- & $\ldots$ & -- & -- & -- \\
\hline $7 / 26 / 1960$ & 11 & 5 & 5 & King(G), Szymczak (G) & $10-0$ & Yes & Maintain & 1 & 0 & -- & - & -- & -- & -- \\
\hline $8 / 16 / 1960$ & 12 & 6 & 5 & $\operatorname{Martin}(\mathrm{G})$ & $7-4$ & 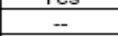 & Decrease restraint & 1 & 0 & 4 & 4 & - & -- & -- \\
\hline $9 / 13 / 1960$ & 13 & 7 & 5 & - & $12-0$ & Yes & Maintain & 1 & 0 & - & - & -- & -- & -- \\
\hline $10 / 4 / 1960$ & 14 & 7 & 5 & - & $12-0$ & Yes & Maintain & 1 & 0 & - & - & -- & -- & -- \\
\hline $10 / 25 / 1960$ & 15 & 6 & 5 & Szymczak (G) & $11-0$ & Yes & Maintain & 1 & 1 & $\ldots$ & -- & -- & -- & -- \\
\hline $11 / 22 / 1960$ & 16 & $\frac{0}{7}$ & 5 & - & $12-0$ & -- & Maintain & 1 & $\frac{1}{1}$ & - & $-\overline{-}$ & -- & - & $-\overline{-}$ \\
\hline $12 / 13 / 1960$ & 17 & 7 & 5 & - & $12-0$ & - & Maintain & 1 & 1 & -- & - & -- & -- & -- \\
\hline $1 / 10 / 1961$ & 1 & 7 & 5 & - & $12-0$ & - & Maintain & 1 & 1 & -- & - & -- & -- & - \\
\hline $1 / 24 / 1961$ & 2 & 7 & 5 & - & $12-0$ & - & Maintain & 1 & 1 & $\ldots$ & $\ldots$ & -- & -- & -- \\
\hline $2 / 7 / 1961$ & 3 & 7 & 5 & - & $12-0$ & -- & Maintain & 1 & 1 & - & - & -- & -- & -- \\
\hline $3 / 7 / 1961$ & 4 & 7 & 5 & - & $12-0$ & -- & Maintain & 1 & 1 & - & - & -- & -- & -- \\
\hline $3 / 28 / 1961$ & $\frac{4}{5}$ & $\frac{1}{7}$ & 5 & $\ddot{z}$ & $\mid 12-0$ & -- & Maintain & 1 & $\frac{1}{1}$ & 3 & -- & 3 & -- & -- \\
\hline $4 / 18 / 1961$ & 6 & 5 & 5 & $\operatorname{Martin}(G), \operatorname{Mitchel}(G)$ & $10-0$ & - & Maintain & 1 & 1 & 3 & -- & 3 & -- & -- \\
\hline $5 / 19 / 1961$ & 7 & 5 & 5 & $\operatorname{Martin}(\mathrm{G}), \operatorname{Mitchel}(\mathrm{G})$ & $10-0$ & -- & Maintain & 1 & 1 & 2 & - & 2 & -- & -- \\
\hline $6 / 6 / 1961$ & 8 & $\frac{5}{6}$ & 5 & Mitchel (G) & $11-0$ & Yes & Maintain & 1 & $\frac{1}{1}$ & -- & - & -- & -- & - \\
\hline $6 / 21 / 1961$ & 9 & 5 & 5 & Mitchel (G), King (G) & $10-0$ & - & Maintain & 1 & 1 & -- & -- & -- & -- & -- \\
\hline $7 / 11 / 1961$ & 10 & 6 & 5 & Mitchel (G) & $11-0$ & -- & Maintain & 1 & 1 & 1 & -- & -- & 1 & -- \\
\hline $8 / 1 / 1961$ & 11 & 5 & 5 & Mitchel (G), Robertson (G) & $10-0$ & -- & Maintain & 1 & 1 & 1 & -- & -- & 1 & -- \\
\hline $8 / 22 / 1961$ & 12 & 5 & 5 & Mitchell (G), Shepardson (G) & $10-0$ & -. & Maintain & 1 & 1 & 1 & -- & -- & 1 & -- \\
\hline $9 / 12 / 1961$ & 13 & 6 & 5 & Mills $(G)$ & $11-0$ & Yes & Maintain & 1 & 1 & - & - & - & -- & -- \\
\hline $10 / 3 / 1961$ & 14 & 6 & 5 & Martin (G) & $11-0$ & Yes & Maintain & 1 & 1 & 1 & -. & -- & 1 & -- \\
\hline $10 / 24 / 1961$ & 15 & 6 & 5 & Martin (G) & $11-0$ & $\ldots$ & Maintain & 1 & 1 & 1 & -- & -- & 1 & -- \\
\hline $11 / 14 / 1961$ & 16 & 5 & 5 & Balderston (G), Shepardson (G) & $10-0$ & -- & Maintain & 1 & 1 & 2 & -- & -- & 2 & -- \\
\hline $12 / 5 / 1961$ & 17 & 7 & 5 & -- & $12-0$ & -- & Maintain & 1 & 1 & $\ldots$ & -- & -- & -- & -- \\
\hline $12 / 19 / 1961$ & 18 & 7 & 5 & - & \begin{tabular}{|c|}
$8-4$ \\
\end{tabular} & -- & Increase restraint & 1 & 1 & 4 & 2 & -- & 1 & 1 \\
\hline $1 / 9 / 1962$ & 1 & 7 & 5 & $\ldots$ & $12-0$ & Yes & Maintain & 1 & 1 & - & - & -- & -- & - \\
\hline $1 / 23 / 1962$ & 2 & 7 & 5 & $\ldots$ & $12-0$ & Yes & Maintain & 1 & 1 & -- & -- & $-\ldots$ & -- & -- \\
\hline $2 / 13 / 1962$ & 3 & 7 & 5 & - & $12-0$ & Yes & Maintain & 1 & 1 & -- & -- & -- & -- & -- \\
\hline
\end{tabular}




\begin{tabular}{|c|c|c|c|c|c|c|c|c|c|c|c|c|c|c|}
\hline \multirow[b]{2}{*}{ Date } & \multirow[b]{2}{*}{ Meeting } & \multicolumn{2}{|c|}{ Attendance } & \multirow[b]{2}{*}{ Absent } & \multirow[b]{2}{*}{ Vote } & \multirow[b]{2}{*}{ Even Keel } & \multirow[b]{2}{*}{ Policy Decision at Meeting } & \multicolumn{2}{|c|}{ Reason for Directive } & \multirow[b]{2}{*}{ Total Dissents } & \multicolumn{4}{|c|}{ Direction of Dissent } \\
\hline & & \begin{tabular}{|l|} 
Governors \\
\end{tabular} & President & & & & & Domestic & International & & Maintain & Ease & Tighten & Non-Mon \\
\hline $3 / 6 / 1962$ & \begin{tabular}{|l|l|}
4 & \\
\end{tabular} & \begin{tabular}{|l|}
5 \\
\end{tabular} & 5 & King (G), Mills (G) & \begin{tabular}{|l|}
$10-0$ \\
\end{tabular} & \begin{tabular}{|c|}
-- \\
\end{tabular} & Maintain & 1 & \begin{tabular}{|l|}
1 \\
\end{tabular} & $\begin{array}{c}-- \\
\end{array}$ & -- & $\ldots$ & $-\cdots$ & \begin{tabular}{|c|}
-- \\
\end{tabular} \\
\hline $3 / 27 / 1962$ & 5 & 6 & 5 & King $(G)$ & \begin{tabular}{|l|}
$10-1$ \\
\end{tabular} & -- & Maintain & 1 & 1 & 1 & -- & -- & 1 & -- \\
\hline $4 / 17 / 1962$ & 6 & 7 & 5 & $\ldots$ & \begin{tabular}{|l|}
$11-1$ \\
\end{tabular} & Yes & Maintain & 1 & 1 & 2 & -- & -- & 2 & - \\
\hline $5 / 8 / 1962$ & 7 & 7 & 5 & - & \begin{tabular}{|l|l|}
$11-1$ \\
\end{tabular} & -- & Maintain & 1 & 1 & 1 & -- & - & 1 & - \\
\hline $5 / 29 / 1962$ & 8 & 7 & 5 & - & $12-0$ & -- & Maintain & 1 & 1 & -- & -- & -- & -- & -- \\
\hline $6 / 19 / 1962$ & 9 & 6 & 5 & Mitchell (G) & \begin{tabular}{|l|l|}
$9-2$ \\
\end{tabular} & -- & Increase restraint & 1 & 1 & 2 & 2 & -- & -- & -- \\
\hline 7/10/1962 & 10 & 7 & 5 & - & $10-2$ & -- & Maintain & 1 & 1 & 2 & -- & 2 & -- & - \\
\hline $7 / 31 / 1962$ & 11 & 7 & 5 & -- & \begin{tabular}{|l|}
$10-2$ \\
\end{tabular} & -- & Maintain & 1 & 1 & 2 & -- & 2 & -- & -- \\
\hline $8 / 21 / 1962$ & 12 & 6 & 5 & Robertson (G) & \begin{tabular}{|l|l|}
$9-2$ \\
\end{tabular} & -- & Maintain & 1 & 1 & 2 & -- & 2 & -- & - \\
\hline $9 / 11 / 1962$ & 13 & 7 & 5 & & \begin{tabular}{|c|}
$9-3$ \\
\end{tabular} & -- & Maintain & 1 & 1 & 3 & -- & 3 & -- & -- \\
\hline $10 / 2 / 1962$ & 14 & 5 & 5 & King (G), Robertson (G) & \begin{tabular}{|l|}
$8-2$ \\
\end{tabular} & -- & Maintain & 1 & 1 & 2 & -- & 2 & -- & -- \\
\hline $10 / 23 / 1962$ & 15 & 6 & 5 & Robertson (G) & $11-0$ & Yes & Maintain & 1 & 1 & -- & -- & -- & -- & - \\
\hline $11 / 13 / 1962$ & 16 & 6 & 5 & Shepardson (G) & \begin{tabular}{|l|}
$10-1$ \\
\end{tabular} & $\begin{array}{c}-- \\
\end{array}$ & Maintain & 1 & 1 & 1 & -- & 1 & -- & - \\
\hline 12/4/1962 & 17 & 7 & 5 & -- & 11-1 & -- & Maintain & 1 & 1 & 1 & - & 1 & -- & -- \\
\hline $12 / 18 / 1962$ & 18 & 7 & 5 & - & $7-5$ & -- & Increase restraint & 0 & 1 & 5 & 5 & -- & -- & -- \\
\hline 1/8/1963 & 1 & 6 & 5 & Mitchell (G) & $10-1$ & Yes & Maintain & 1 & 1 & 1 & 1 & -- & -- & -- \\
\hline $1 / 29 / 1963$ & 2 & 6 & 5 & King (G) & \begin{tabular}{|l|l|}
$11-0$ \\
\end{tabular} & Yes & Maintain & 1 & 1 & -- & -- & -- & -- & -- \\
\hline $2 / 12 / 1963$ & 3 & 5 & 5 & King (G), Mills (G) & $10-0$ & Yes & Maintain & 1 & 1 & -- & -- & -- & -- & -- \\
\hline $3 / 5 / 1963$ & 4 & 6 & 5 & King (G) & $11-0$ & Yes & Maintain & 1 & 1 & -- & -- & -- & -- & - \\
\hline $3 / 26 / 1963$ & 5 & 7 & 5 & $\ldots$ & 11-1 & Yes & Maintain & 1 & 1 & 1 & -- & -- & 1 & - \\
\hline $4 / 16 / 1963$ & 6 & 7 & 5 & - & \begin{tabular}{|l|}
$10-2$ \\
\end{tabular} & Yes & Maintain & 1 & 1 & 2 & -- & 1 & 1 & -- \\
\hline $5 / 7 / 1963$ & 7 & 6 & 5 & Mills (G) & \begin{tabular}{|l|}
$6-5$ \\
\end{tabular} & -- & Increase restraint & 0 & 1 & 5 & 5 & -- & -- & -- \\
\hline $5 / 28 / 1963$ & 8 & 6 & 5 & Robertson (G) & $10-1$ & -- & Maintain & 1 & 1 & 1 & -- & 1 & -- & -- \\
\hline $6 / 18 / 1963$ & 9 & 5 & 5 & King (G), Robertson (G) & \begin{tabular}{|l|l|}
$7-3$ \\
\end{tabular} & -- & Maintain & 1 & 1 & 3 & -- & 1 & 2 & - \\
\hline $\begin{array}{l}7 / 9 / 1963 \\
\end{array}$ & 10 & 7 & 5 & - & $10-2$ & -- & Maintain & 1 & 1 & 2 & -- & 2 & - & -- \\
\hline $7 / 30 / 1963$ & 11 & 6 & 4 & King (G), Clay (KC) & \begin{tabular}{|l|}
$6-4$ \\
\end{tabular} & -- & Increase restraint & 0 & 1 & 4 & 4 & -- & -- & -- \\
\hline $8 / 20 / 1963$ & 12 & 6 & 5 & King $(\mathrm{G})$ & \begin{tabular}{|l|}
$11-0$ \\
\end{tabular} & Yes & Maintain & 1 & 1 & -- & -- & -- & -- & -- \\
\hline 9/10/1963 & 13 & 6 & 5 & Mills (G) & $11-0$ & Yes & Maintain & 1 & 1 & -- & -- & -- & -- & - \\
\hline $10 / 1 / 1963$ & 14 & 6 & 5 & King $(G)$ & \begin{tabular}{|l|}
$7-4$ \\
\end{tabular} & $\ldots$ & Maintain & 1 & 1 & 4 & -- & -- & 4 & - \\
\hline $10 / 22 / 1963$ & 15 & 6 & 5 & King $(G)$ & \begin{tabular}{|l|}
$11-0$ \\
\end{tabular} & Yes & Maintain & 1 & 1 & -- & -- & -- & -- & - \\
\hline $11 / 12 / 1963$ & 16 & 6 & 5 & King $(G)$ & $10-1$ & -- & Maintain & 1 & 1 & 1 & -- & 1 & -- & - \\
\hline $11 / 26 / 1963$ & 17 & 6 & 5 & King $(G)$ & $10-1$ & -- & Maintain & 1 & 1 & 1 & -- & 1 & -- & - \\
\hline $12 / 3 / 1963$ & 18 & 6 & 5 & $\operatorname{King}(G)$ & \begin{tabular}{|l|}
$10-1$ \\
\end{tabular} & -- & Maintain & 1 & 1 & 1 & -- & 1 & -- & -- \\
\hline $12 / 17 / 1963$ & 19 & 6 & 5 & Balderston (G) & \begin{tabular}{|l|}
$9-2$ \\
\end{tabular} & -- & Maintain & 1 & 1 & 2 & -- & -- & 1 & 1 \\
\hline \begin{tabular}{ll|}
$1 / 7 / 1964$ \\
\end{tabular} & 1 & 7 & 5 & - & \begin{tabular}{|l|}
$11-1$ \\
\end{tabular} & Yes & Maintain & 1 & 1 & 1 & -- & 1 & -- & -- \\
\hline $1 / 28 / 1964$ & 2 & 6 & 5 & Daane (G) & $10-0$ & Yes & Maintain & 1 & 1 & -- & -- & -- & -- & -- \\
\hline $2 / 11 / 1964$ & 3 & 7 & 5 & -- & \begin{tabular}{|l|}
$11-0$ \\
\end{tabular} & -- & Maintain & 1 & 1 & -- & -- & -- & -- & - \\
\hline $3 / 3 / 1964$ & 4 & 7 & 5 & 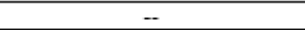 & 11-1 & -- & Maintain & 1 & 1 & 1 & -- & 1 & -- & -- \\
\hline $3 / 24 / 1964$ & 5 & 7 & 5 & $\ddot{-}$ & \begin{tabular}{|l|}
$11-1$ \\
\end{tabular} & Yes & Maintain & 1 & 1 & 1 & -- & 1 & -- & -- \\
\hline $4 / 14 / 1964$ & 6 & 6 & 5 & Robertson (G) & \begin{tabular}{|l|}
$8-3$ \\
\end{tabular} & Yes & Maintain & 1 & 1 & 3 & -- & -- & 2 & -- \\
\hline $5 / 5 / 1964$ & 7 & 7 & 5 & $\ldots$ & $12-0$ & Yes & Maintain & 1 & 1 & -- & -- & -- & -- & - \\
\hline $5 / 26 / 1964$ & 8 & 6 & 5 & Martin (G) & 11-0 & -- & Maintain & 1 & 1 & -- & -- & -- & -- & - \\
\hline $6 / 17 / 1964$ & 9 & 5 & 5 & Balderston (G), Daane (G) & $9-1$ & Yes & Maintain & 1 & 1 & 1 & -- & 1 & -- & -- \\
\hline $7 / 7 / 1964$ & 10 & 6 & 5 & Mitchell (G) & \begin{tabular}{|l|l|}
$11-0$ \\
\end{tabular} & Yes & Maintain & 1 & 1 & -- & -- & - & -- & -- \\
\hline $7 / 28 / 1964$ & 11 & 7 & 5 & & \begin{tabular}{|c|}
$12-0$ \\
\end{tabular} & Yes & Maintain & 1 & 1 & -- & -- & -- & -- & -- \\
\hline $8 / 18 / 1964$ & 12 & 6 & 5 & Shepardson (G) & \begin{tabular}{|l|l|}
$6-5$ \\
\end{tabular} & -- & Increase restraint & 1 & 1 & 5 & 5 & -- & -- & -- \\
\hline $9 / 8 / 1964$ & 13 & 5 & 5 & Martin (G), Daane (G) & $10-0$ & -- & Maintain & 1 & 1 & -- & -- & -- & -- & -- \\
\hline $9 / 29 / 1964$ & 14 & 7 & 5 & - & \begin{tabular}{|l|}
$12-0$ \\
\end{tabular} & -- & Maintain & 1 & 1 & -- & -- & -- & -- & -- \\
\hline $10 / 20 / 1964$ & 15 & 7 & 5 & - & \begin{tabular}{|c|}
$12-0$ \\
\end{tabular} & Yes & Maintain & 1 & 1 & -- & -- & -- & -- & -- \\
\hline 11/10/1964 & 16 & 7 & 5 & - & $11-1$ & Yes & Maintain & 1 & 1 & 1 & -- & - & 1 & - \\
\hline $12 / 1 / 1964$ & 17 & 5 & 5 & Daane (G), Mills (G) & $10-0$ & -- & Increase restraint & 0 & 1 & -- & -- & -- & -- & -- \\
\hline $12 / 15 / 1964$ & 18 & 6 & 5 & Daane (G) & \begin{tabular}{|l|}
$10-1$ \\
\end{tabular} & -- & Maintain & 1 & 1 & 1 & -- & - & 1 & -- \\
\hline $1 / 12 / 1965$ & 1 & 6 & 5 & Mills (G) & \begin{tabular}{|l|}
$11-0$ \\
\end{tabular} & Yes & Maintain & 1 & 1 & -- & -- & - & -- & - \\
\hline $2 / 2 / 1965$ & 2 & 7 & 5 & & \begin{tabular}{|l|}
$10-2$ \\
\end{tabular} & -- & Increase restraint & 1 & 1 & 2 & 2 & -- & -- & -- \\
\hline $3 / 2 / 1965$ & 3 & 6 & 5 & Mills (G) & $8-3$ & -- & Maintain & 1 & 1 & 3 & - & - & 3 & - \\
\hline $3 / 23 / 1965$ & 4 & 6 & 5 & Mills (G) & \begin{tabular}{|l|l}
$8-3$ & \\
\end{tabular} & -- & Increase restraint & 1 & 1 & 3 & 3 & -- & -- & -- \\
\hline
\end{tabular}




\begin{tabular}{|c|c|c|c|c|c|c|c|c|c|c|c|c|c|c|}
\hline \multirow[b]{2}{*}{ Date } & \multirow[b]{2}{*}{ Meeting } & \multicolumn{2}{|c|}{ Attendance } & \multirow[b]{2}{*}{ Absent } & \multirow[b]{2}{*}{ Vote } & \multirow[b]{2}{*}{ Even Keel } & \multirow[b]{2}{*}{ Policy Decision at Meeting } & \multicolumn{2}{|c|}{ Reason for Directive } & \multirow[b]{2}{*}{ Total Dissents } & \multicolumn{4}{|c|}{ Direction of Dissent } \\
\hline & & \begin{tabular}{|l|} 
Governors \\
\end{tabular} & President & & & & & \begin{tabular}{|l|l|} 
Domestic \\
\end{tabular} & International & & Maintain & Ease & Tighten & Non-Mon \\
\hline $4 / 13 / 1965$ & 5 & 6 & 5 & Mills (G) & \begin{tabular}{|l|l|}
$11-0$ \\
\end{tabular} & \begin{tabular}{|l|} 
Yes \\
\end{tabular} & Maintain & 1 & 1 & -- & -- & -- & -- & $\ldots$ \\
\hline $5 / 11 / 1965$ & 6 & 6 & 5 & Mitchell (G) & \begin{tabular}{|l|}
$11-0$ \\
\end{tabular} & Yes & Maintain & 1 & 1 & -- & -- & -- & -- & -- \\
\hline $5 / 25 / 1965$ & 7 & 7 & 5 & - & $8-4$ & -- & Maintain & 1 & 1 & 4 & -- & -- & 4 & -- \\
\hline $6 / 15 / 1965$ & 8 & 6 & 5 & Balderston (G) & $11-0$ & -- & Maintain & 1 & 1 & -- & -- & -- & -- & -- \\
\hline $7 / 13 / 1965$ & 9 & 7 & 5 & - & \begin{tabular}{|l|}
$11-1$ \\
\end{tabular} & Yes & Maintain & 1 & 1 & 1 & -- & -- & 1 & -- \\
\hline $8 / 10 / 1965$ & 10 & 6 & 5 & Daane (G) & \begin{tabular}{|l|l|}
$11-0$ \\
\end{tabular} & Yes & Maintain & 1 & 1 & -- & -- & -- & -- & -- \\
\hline $8 / 31 / 1965$ & 11 & 7 & 5 & $\ldots$ & \begin{tabular}{|l|}
$11-1$ \\
\end{tabular} & $\ldots$ & Maintain & 1 & 1 & 1 & -- & -- & 1 & -- \\
\hline 9/28/1965 & 12 & 7 & 5 & -. & \begin{tabular}{|l|}
$9-3$ \\
\end{tabular} & Yes & Maintain & 1 & 1 & 3 & -- & 3 & -- & -- \\
\hline $10 / 12 / 1965$ & 13 & 7 & 5 & 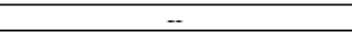 & \begin{tabular}{|l|}
$12-0$ \\
\end{tabular} & Yes & Maintain & 1 & 1 & -- & -- & -- & -- & -- \\
\hline $11 / 2 / 1965$ & 14 & 7 & 5 & -. & $12-0$ & Yes & Maintain & 1 & 1 & -- & -- & -. & -. & -. \\
\hline $11 / 23 / 1965$ & 15 & 7 & 5 & -. & \begin{tabular}{|c|}
$12-0$ \\
\end{tabular} & $\ldots$ & Maintain & 1 & 1 & -- & -- & -- & -- & -- \\
\hline $12 / 14 / 1965$ & 16 & 6 & 5 & Daane (G) & \begin{tabular}{|c|}
$11-0$ \\
\end{tabular} & Yes & Increase restraint & 1 & 1 & -- & -- & -- & -- & -- \\
\hline $1 / 11 / 1966$ & 1 & 7 & 5 & $\ldots$ & \begin{tabular}{|l|}
$12-0$ \\
\end{tabular} & Yes & Maintain & 1 & 1 & -- & -- & -- & -- & -- \\
\hline $2 / 8 / 1966$ & 2 & 7 & 5 & -. & \begin{tabular}{|c|}
$12-0$ \\
\end{tabular} & Yes & Increase restraint & 1 & 1 & -- & -- & -. & -. & -- \\
\hline $3 / 1 / 1966$ & 3 & 6 & 5 & Balderston (G) & \begin{tabular}{|c|}
$11-0$ \\
\end{tabular} & -- & Increase restraint & 1 & 1 & -- & -- & -- & - & -- \\
\hline $3 / 22 / 1966$ & 4 & 7 & 5 & -- & $12-0$ & -- & Increase restraint & 1 & 1 & -- & -- & -- & -- & -- \\
\hline $4 / 12 / 1966$ & 5 & 6 & 5 & Robertson (G) & \begin{tabular}{|l|}
$11-0$ \\
\end{tabular} & Yes & Increase restraint & 1 & 1 & -- & -- & -- & -- & -- \\
\hline $5 / 10 / 1966$ & 6 & 7 & 5 & - & $12-0 \mid$ & Yes & Increase restraint & 1 & 1 & -- & -- & -- & -- & -- \\
\hline $6 / 7 / 1966$ & 7 & 6 & 5 & Daane (G) & \begin{tabular}{|l|l|}
$11-0$ \\
\end{tabular} & -- & Maintain & 1 & 1 & -- & -- & -- & -- & -- \\
\hline $6 / 28 / 1966$ & 8 & 5 & 5 & Robertson (G), Shepardson (G) & \begin{tabular}{|c|}
$10-0$ \\
\end{tabular} & -- & Maintain & 1 & 1 & -- & -- & -- & -- & -- \\
\hline $7 / 26 / 1966$ & 9 & 5 & 5 & Martin (G), Daane (G) & \begin{tabular}{|c|}
$10-0$ \\
\end{tabular} & Yes & Maintain & 1 & 1 & -- & -- & -- & -- & -- \\
\hline $8 / 23 / 1966$ & 10 & 6 & 5 & Martin (G) & \begin{tabular}{|l|l|l|l|l|}
$11-0$ \\
\end{tabular} & $\ldots$ & Maintain & 1 & 1 & -- & -- & -- & -- & -- \\
\hline $9 / 13 / 1966$ & 11 & 7 & 5 & $\ldots$ & $12-0$ & -- & Maintain & 1 & 1 & -- & -- & -. & -. & -- \\
\hline $10 / 4 / 1966$ & 12 & 7 & 5 & -- & $12-0$ & Yes & Maintain & 1 & 1 & -- & -- & -- & -- & -- \\
\hline $11 / 1 / 1966$ & 13 & 7 & 5 & - & \begin{tabular}{|c|}
$12-0$ \\
\end{tabular} & Yes & Maintain & 1 & 1 & -- & -- & -- & -- & -- \\
\hline $11 / 22 / 1966$ & 14 & 7 & 5 & - & $\mid 10-2$ & -- & Decrease restraint & 1 & 0 & 2 & 2 & -- & -- & -- \\
\hline $12 / 13 / 1966$ & 15 & 7 & 5 & -- & \begin{tabular}{|l|}
$8-4$ \\
\end{tabular} & -- & Decrease restraint & 1 & 0 & 4 & 4 & -- & -- & -- \\
\hline $1 / 10 / 1967$ & 1 & 7 & 5 & - & \begin{tabular}{|l|}
$9-3$ \\
\end{tabular} & Yes & Decrease restraint & 1 & 0 & 3 & 3 & - & - & -- \\
\hline $2 / 7 / 1967$ & 2 & 7 & 5 & -- & \begin{tabular}{|l|}
$11-1$ \\
\end{tabular} & Yes & Maintain & 1 & 1 & 1 & -- & 1 & -- & -- \\
\hline $3 / 7 / 1967$ & 3 & 7 & 5 & - & $\mid 12-0$ & -- & Decrease restraint & 1 & 0 & -- & -- & -- & -- & -- \\
\hline $4 / 4 / 1967$ & 4 & 7 & 5 & -- & \begin{tabular}{|l|}
$12-0$ \\
\end{tabular} & -- & Decrease restraint & 1 & 0 & -- & -- & -- & -- & -- \\
\hline $5 / 2 / 1967$ & 5 & 7 & 5 & -- & $12-0$ & Yes & Maintain & 1 & 1 & -- & -- & -- & -- & -- \\
\hline $5 / 23 / 1967$ & 6 & 7 & 5 & - & \begin{tabular}{|l|}
$11-1$ \\
\end{tabular} & $\ldots$ & Maintain & 1 & 1 & 1 & -- & -- & 1 & -- \\
\hline $6 / 20 / 1967$ & 7 & 6 & 5 & Daane (G) & \begin{tabular}{|l|}
$11-0$ \\
\end{tabular} & Yes & Maintain & 1 & 1 & - & -- & -- & -- & -- \\
\hline $7 / 18 / 1967$ & 8 & 5 & 5 & $\operatorname{Martin}(G)$, Daane (G) & \begin{tabular}{|l|}
$10-0$ \\
\end{tabular} & Yes & Maintain & 1 & 1 & -- & -- & -- & -- & -- \\
\hline $8 / 15 / 1967$ & 9 & 6 & 5 & Martin (G) & \begin{tabular}{|c|}
$11-0$ \\
\end{tabular} & Yes & Maintain & 1 & 1 & -- & -- & -- & -- & -- \\
\hline $9 / 12 / 1967$ & 10 & 7 & 5 & -- & \begin{tabular}{|l|l|}
$9-3$ \\
\end{tabular} & -- & Maintain & 1 & 1 & 3 & -- & -- & 3 & -- \\
\hline $10 / 3 / 1967$ & 11 & 6 & 5 & Martin (G) & $9-2$ & Yes & Maintain & 1 & 1 & 2 & -- & -- & 2 & -- \\
\hline $10 / 24 / 1967$ & 12 & 6 & 5 & Daane (G) & \begin{tabular}{|l|}
$10-1$ \\
\end{tabular} & Yes & Maintain & 1 & 1 & 1 & -- & -- & 1 & -- \\
\hline $11 / 14 / 1967$ & 13 & 7 & 5 & - & \begin{tabular}{|l|}
$12-0$ \\
\end{tabular} & $\ldots$ & Maintain & 1 & 1 & -- & -- & -- & -- & -- \\
\hline $11 / 27 / 1967$ & 14 & 6 & 4 & Hayes (NY), Daane (G) & $10-0$ & -- & Increase restraint & 0 & 1 & -- & -- & -- & -- & -- \\
\hline $12 / 12 / 1967$ & 15 & 6 & 5 & Daane (G) & \begin{tabular}{|c|}
$10-1$ \\
\end{tabular} & -- & Increase restraint & 1 & 1 & 1 & 1 & -- & -- & -- \\
\hline $1 / 9 / 1968$ & 1 & 7 & 5 & $\ldots$ & \begin{tabular}{|l|}
$12-0$ \\
\end{tabular} & -- & Maintain & 1 & 1 & -- & -- & -- & -- & -- \\
\hline $2 / 6 / 1968$ & 2 & 7 & 5 & -- & \begin{tabular}{|c|}
$12-0$ \\
\end{tabular} & -- & Maintain & 1 & 1 & -- & -- & -- & -- & -- \\
\hline $3 / 5 / 1968$ & 3 & 6 & 5 & Daane (G) & $11-0$ & -- & Increase restraint & 1 & 1 & -- & -- & -- & -- & -- \\
\hline $3 / 14 / 1968$ & 4 & 7 & 5 & - & $12-0$ & -- & Increase restraint & 0 & 1 & -- & -- & -- & -- & -- \\
\hline $4 / 2 / 1968$ & 5 & 7 & 5 & -- & $12-0$ & -- & Increase restraint & 1 & 1 & -- & -- & -- & -- & -- \\
\hline $4 / 19 / 1968$ & 6 & 6 & 5 & Sherrill (G) & \begin{tabular}{|l|}
$11-0$ \\
\end{tabular} & -- & Increase restraint & 0 & 1 & - & -- & -- & -- & -- \\
\hline $4 / 30 / 1968$ & 7 & 6 & 5 & Mitchell (G) & \begin{tabular}{|l|}
$10-1$ \\
\end{tabular} & Yes & Maintain & 1 & 1 & 1 & -- & -- & -- & -- \\
\hline $5 / 28 / 1968$ & 8 & 7 & 5 & -- & $12-0$ & -- & Maintain & 1 & 1 & -- & -- & -- & -- & -- \\
\hline $6 / 18 / 1968$ & 9 & 7 & 5 & -- & $\mid 12-0$ & -- & Maintain & 1 & 1 & -- & -- & -- & -- & -- \\
\hline $7 / 16 / 1968$ & 10 & 7 & 5 & - & \begin{tabular}{|l|}
$12-0$ \\
\end{tabular} & Yes & Decrease restraint & 1 & 0 & -- & -- & -- & - & -- \\
\hline $8 / 13 / 1968$ & 11 & 7 & 5 & -. & $12-0$ & $\ldots$ & Maintain & 1 & 1 & -- & -- & -- & - & -- \\
\hline $8 / 19 / 1968$ & 12 & 5 & 5 & Martin (G), Mitchell (G) & $10-0$ & -- & Maintain & 1 & 0 & -- & -- & -- & -- & -- \\
\hline $9 / 10 / 1968$ & 13 & 7 & 5 & - & \begin{tabular}{|c|}
$12-0$ \\
\end{tabular} & -- & Maintain & 1 & 1 & -- & -- & -- & -- & -- \\
\hline $10 / 8 / 1968$ & 14 & 7 & 5 & - & \begin{tabular}{|l|l|}
$9-3$ \\
\end{tabular} & Yes & Maintain & 1 & 1 & 3 & -- & -- & 3 & -- \\
\hline
\end{tabular}




\begin{tabular}{|c|c|c|c|c|c|c|c|c|c|c|c|c|c|c|}
\hline \multirow[b]{2}{*}{ Date } & \multirow[b]{2}{*}{ Meeting } & \multicolumn{2}{|c|}{ Attendance } & \multirow[b]{2}{*}{ Absent } & \multirow[b]{2}{*}{ Vote } & \multirow[b]{2}{*}{ Even Keel } & \multirow[b]{2}{*}{ Policy Decision at Meeting } & \multicolumn{2}{|c|}{ Reason for Directive } & \multirow[b]{2}{*}{ Total Dissents } & \multicolumn{4}{|c|}{ Direction of Dissent } \\
\hline & & Governors & President & & & & & Domestic & International & & Maintain & Ease & Tighten & Non-Mon \\
\hline $10 / 29 / 1968$ & 15 & 7 & 5 & - & 11-1 & Yes & Maintain & 1 & 1 & 1 & -- & - & 1 & -- \\
\hline $11 / 26 / 1968$ & 16 & 7 & 5 & $\ldots$ & $8-4$ & -. & Maintain & 1 & 1 & 4 & -- & -- & 4 & -- \\
\hline $12 / 17 / 1968$ & 17 & 6 & 5 & Martin (G) & $11-0$ & -- & Increase restraint & 1 & 1 & -- & -- & - & -- & -- \\
\hline $1 / 14 / 1969$ & 1 & 7 & 5 & $\ldots$ & $11-1$ & Yes & Maintain & 1 & 1 & 1 & -. & 1 & -- & $\ldots$ \\
\hline $2 / 4 / 1969$ & 2 & 7 & 5 & - & $12-0$ & Yes & Maintain & 1 & 1 & - & - & - & -- & - \\
\hline $3 / 4 / 1969$ & 3 & 7 & 5 & $\ldots$ & $12-0$ & -. & Maintain & 1 & 1 & $\ldots$ & -. & -- & -- & $\ldots$ \\
\hline $4 / 1 / 1969$ & 4 & 7 & 5 & - & $10-2$ & -- & Increase restraint & 1 & 1 & 2 & 1 & - & 1 & -- \\
\hline $4 / 29 / 2008$ & 5 & 6 & 5 & Sherrill (G) & $11-0$ & Yes & Increase restraint & 1 & 1 & -- & -- & -- & -- & -- \\
\hline $5 / 27 / 1969$ & 6 & 7 & 5 & - & $12-0$ & - & Maintain & 1 & 1 & - & - & - & -- & - \\
\hline $6 / 24 / 1969$ & 7 & 7 & 5 & -. & $11-1$ & -- & Maintain & 1 & 1 & 1 & -- & 1 & -- & -- \\
\hline $7 / 15 / 1969$ & 8 & 6 & 5 & Mitchell (G) & $11-0$ & Yes & Maintain & 1 & 1 & -- & -- & -- & -- & -- \\
\hline $8 / 12 / 1969$ & 9 & 7 & 5 & $\ldots$ & $10-2$ & $\ldots$ & Maintain & 1 & 1 & 2 & -- & -- & -- & 2 \\
\hline $9 / 9 / 1969$ & 10 & 5 & 5 & Daane (G) \& Robertson (G) & $8-2$ & Yes & Maintain & 1 & 1 & 1 & - & - & -- & 1 \\
\hline $10 / 7 / 1969$ & 11 & 7 & 5 &.- & $11-1$ &.- & Maintain & 1 & 1 & -- & - & - & $\ldots$ & -- \\
\hline $10 / 28 / 1969$ & 12 & 7 & 5 & $\ldots$ & $12-0$ & $\ldots$ & Maintain & 1 & 1 & $\ldots$ & -. & $\ldots$ & $\ldots$ & $\ldots$ \\
\hline $11 / 25 / 1969$ & 13 & 6 & 5 & Maisel (G) & $11-0$ & -- & Maintain & 1 & 1 & -- & -- & -- & -- & -- \\
\hline $12 / 16 / 1969$ & 14 & 6 & 5 & Daane (G) & $11-0$ & - & Maintain & 1 & 1 & -- & -- & -- & -- & -- \\
\hline $1 / 15 / 1970$ & 1 & 7 & 5 & $\ldots$ & $12-0$ & Yes & Maintain & 1 & 1 & $\ldots$ & $\ldots$ & -. & -. & $\ldots$ \\
\hline $2 / 10 / 1970$ & 2 & 7 & 5 & - & $9-3$ & Yes & Decrease restraint & 1 & 0 & 3 & 3 & - & -- & -- \\
\hline $3 / 10 / 1970$ & 3 & 7 & 5 & -- & $12-0$ & -- & Decrease restraint & 1 & 0 & -- & -- & - & -- & -- \\
\hline $4 / 7 / 1970$ & 4 & 7 & 5 & - & $12-0$ & Yes & Increase restraint & 1 & 1 & - & - & - & - & - \\
\hline $5 / 5 / 1970$ & 5 & 7 & 5 & $\ldots$ & $11-1$ & Yes & Decrease restraint & 1 & 0 & 1 & 1 & -- & -. & -- \\
\hline $5 / 26 / 1970$ & 6 & 7 & 5 & $\ldots$ & $12-0$ & $\ldots$ & Decrease restraint & 1 & 0 & -- & - & -. & $\ldots$ & $\ldots$ \\
\hline $6 / 23 / 1970$ & 7 & 7 & 5 & $\ldots$ & $12-0$ & $\ldots$ & Decrease restraint & 1 & 0 & -- & - & $\ldots$ & -- & - \\
\hline $7 / 21 / 1970$ & 8 & 6 & 5 & Mitchell (G) & $11-0$ & Yes & Decrease restraint & 1 & 0 & -- & -- & -- & -- & -- \\
\hline $8 / 18 / 1970$ & 9 & 7 & 5 & - & $9-3$ & -- & Decrease restraint & 1 & 0 & 3 & 1 & - & - & 2 \\
\hline 9/15/1970 & 10 & 6 & 5 & Mitchell (G) & $10-1$ & $\ldots$ & Decrease restraint & 1 & 0 & 1 & 1 & -- & -- & - \\
\hline $10 / 20 / 1970$ & 11 & 6 & 5 & Daane (G) & $10-1$ & Yes & Decrease restraint & 1 & 0 & 1 & - & - & -- & 1 \\
\hline $11 / 17 / 1970$ & 12 & 7 & 5 & -- & $11-1$ & -- & Decrease restraint & 1 & 0 & 1 & -- & 1 & -- & -- \\
\hline $12 / 15 / 1970$ & 13 & 7 & 5 & - & $11-1$ & -- & Maintain & 1 & 1 & 1 & 1 & - & -- & -- \\
\hline $1 / 12 / 1971$ & 1 & 6 & 5 & - & $10-1$ & Yes & Decrease restraint & 1 & 0 & 1 & -- & -- & -- & 1 \\
\hline $2 / 9 / 1971$ & 2 & 6 & 5 & Robertson (G) & $10-1$ & -- & Maintain & 1 & 1 & 1 & -- & -- & -- & 1 \\
\hline $3 / 9 / 1971$ & 3 & 7 & 5 & - & $12-0$ & -- & Maintain & 1 & 1 & -- & - & - & -- & -- \\
\hline $4 / 6 / 1971$ & 4 & 6 & 5 & Mitchell (G) & $9-2$ & Yes & Increase restraint & 1 & 1 & 2 & -- & $\ldots$ & 2 & -- \\
\hline $5 / 11 / 1971$ & 5 & 7 & 5 & -. & $12-0$ & Yes & Increase restraint & 1 & 1 & -- & - & - & -- & -- \\
\hline $6 / 8 / 1971$ & 6 & 7 & 5 & -. & $12-0$ & $\ldots$ & Increase restraint & 1 & 1 & -- & - & - & -- & $\ldots$ \\
\hline $6 / 29 / 1971$ & 7 & 7 & 5 & $\ldots$ & $12-0$ & $\ldots$ & Increase restraint & 1 & 1 & -. & -- & -. & -- & -- \\
\hline 7/27/1971 & 8 & 7 & 5 & - & $12-0$ & Yes & Increase restraint & 1 & 1 & -- & - & - & - & - \\
\hline $8 / 24 / 1971$ & 9 & 7 & 5 & $\ldots$ & $12-0$ & $\ldots$ & Increase restraint & 1 & 1 & -- & -- & -- & $\ldots$ & -- \\
\hline 9/21/1971 & 10 & 7 & 5 & - & $12-0$ & -- & Decrease restraint & 1 & 0 & -- & -- & -- & -- & -- \\
\hline 10/19/1971 & 11 & 6 & 5 & Daane (G) & $11-0$ & Yes & Decrease restraint & 1 & 0 & -- & -- & -- & -- & -- \\
\hline 11/16/1971 & 12 & 6 & 5 & 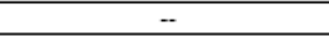 & $11-0$ & Yes & Decrease restraint & 1 & 0 & -- & -- & -- & -- & -- \\
\hline $12 / 14 / 1971$ & 13 & 6 & 5 & -- & $11-0$ & -- & Decrease restraint & 1 & 0 & -- & -- & -- & -- & -- \\
\hline
\end{tabular}




\section{References}

Andrews, Donald W.K. (1993), "Exactly Median-Unbiased Estimation of First Order Autoregressive/Unit Root Models,” Econometrica 61, pp.139-165.

Armeter, Roc and Martin Bodenstein (2005), "Does the Time Inconsistency Problem Make Flexible Exchange Rates Look Worse Than You Think?” Staff Report no. 230, Federal Reserve Bank of Chicago (November).

Bordo, Michael (1993), “The Bretton Woods International Monetary System: A Historical Overview," in Michael Bordo and Barry Eichengreen (eds), A Retrospective on the Bretton Woods System, Chicago: University of Chicago Press, pp.3-108.

Cecchetti, Steven, Peter Hooper, Bruce Kasman, Kermit Schoenholtz and Mark Watson (2007), “Understanding the Evolving Inflation Process,” Initiative on Global Markets, Graduate School of Business, University of Chicago (July).

Chen, Zhaohui and Alberto Giovannini (1992), "Estimating Expected Exchange Rates Under Target Zones,” NBER Working Paper no.3955 (January).

Christiano, Lawrence J. and Christopher Gust (2000), “The Expectations Trap,” Economic Perspectives of the Federal Reserve Bank of Chicago, pp.21-39.

Clarida, Richard, Jordi Gali and Mark Gertler (2000), "Monetary Policy Rules and Macroeconomic Stability: Evidence and Some Theory,” Quarterly Journal of Economics 115, pp.147-180.

Coombs, Charles (1976), The Arena of International Finance, New York: Wiley.

Eichengreen, Barry (2000), "From Benign Neglect to Malignant Preoccupation: U.S. Balance-of-Payments Policy in the 1960s,” in George Perry and James Tobin (eds), Economic Events, Ideas and Policies: The 1960s and After, Washington, D.C.: The Brookings Institution, pp.185-242.

Eichengreen, Barry, Mark Watson and Richard Grossman (1985), "Bank Rate Policy under the Interwar Gold Standard,” Economic Journal 95, pp.725-745.

Markese, John D. (1973), “The Even Keel Policy of the Federal Reserve System - Origin, Definition, Implementation and Import,” Journal of Finance 28, p.766.

Meltzer, Allan (1991), “U.S. Policy in the Bretton Woods Era," Economic Review of the Federal Reserve Bank of St. Louis 73, pp.54-83. 
Meltzer, Allan (forthcoming), A History of the Federal Reserve System, Volume 2, Chicago: University of Chicago Press.

Nelson, Edward (2005), “The Great Inflation of the 1970s: What Really Happened?” Berkeley Electronic Journal of Macroeconomics 5, pp.1-50.

Obstfeld, Maurice (1993), “The Adjustment Mechanism,” in Michael Bordo and Barry Eichengreen (eds), A Retrospective on the Bretton Woods System: Lessons for Monetary Reform, Chicago: University of Chicago Press, pp.201-268.

Orphanides, Athanasios (2003), “The Quest for Prosperity without Inflation,” Journal of Monetary Economics 50, pp.633-663.

Orphanides, Athanasios (2004), “Monetary Policy Rules, Macroeconomic Stability and Inflation: A View from the Trenches,” Journal of Money, Credit and Banking 36, p.151175.

Primiceri, Giorgio (2005), “Why Inflation Rose and Fell: Policy Makers’ Beliefs and Postwar Stabilization Policy,” NBER Working Paper no. 11147 (February).

Romer, Christina and and David Romer (2002a), "The Evolution of Economic Understanding and Postwar Stabilization Policy,” in Rethinking Stabilization Policy, Kansas City, Missouri: Federal Reserve Bank of Kansas City, pp.11-78.

Romer, Christina and David Romer ( 2002b), “A Rehabilitation of Monetary Policy in the 1950s” American Economic Review 92, pp.121-127.

Sargent, Thomas (1999), The Conquest of American Inflation, Princeton: Princeton University Press.

Stock, James and Mark Watson (2002), "Has the Business Cycle Changed and Why?” NBER Macroeconomics Annual 2002, pp.159-218.

Stock, James and Mark Watson (2006), "Why Has Inflation Become Harder to Forecast?” Journal of Money, Credit and Banking 40, p.3-33.

Taylor, John (1992), “The Great Inflation, the Great Disinflation, and Policies for Future Price Stability,” in Adrian Blundell-Wignall (ed.), Inflation, Disinflation and Monetary Policy, Sydney: Ambassador Press, pp.9-34.

Taylor, John (1999), “A Historical Analysis of Monetary Policy Rules,” in John B. Taylor ( ed.), Monetary Policy Rules, Chicago: University of Chicago Press, pp.319-344. 
Taylor, John (1997), “America’s Peacetime Inflation, The 1970s: Comment,” in Christina Romer and David Romer (eds), Reducing Inflation, Chicago: University of Chicago Press, pp.276-280. 